

\section{DISCLAIMER}

This report was prepared as an account of work sponsored by an agency of the United States Government. Neither the United States Government nor any agency Thereof, nor any of their employees, makes any warranty, express or implied, or assumes any legal liability or responsibility for the accuracy, completeness, or usefulness of any information, apparatus, product, or process disclosed, or represents that its use would not infringe privately owned rights. Reference herein to any specific commercial product, process, or service by trade name, trademark, manufacturer, or otherwise does not necessarily constitute or imply its endorsement, recommendation, or favoring by the United States Government or any agency thereof. The views and opinions of authors expressed herein do not necessarily state or reflect those of the United States Government or any agency thereof. 


\section{DISCLAIMER}

Portions of this document may be illegible in electronic image products. Images are produced from the best available original document. 
Oak Ridge Associated Universities is a private, not-for-profit association of 51 colleges and universities. It seeks to help the U.S. Department of Energy, other private and governmental organizations, and its member institutions solve societal problems relating to energy, health, and the environment. Established in 1946, Oak Ridge Associated Universities was one of the first university-based, science-related corporate management groups. Today it conducts diverse, cooperative programs of research, training, education, and information and is noted for its contributions to the development of science and human resources.

The mission of the Manpower Education, Research, and Training Division, formed in 1977, is to enhance the knowledge and abilities of the professional and skilled work force involved in national energy, environmental, and health-related activities. The division is organized into five program areas that examine human resource issues, evaluate manpower requirements and training needs, assist in establishing manpower training programs, and provide opportunities for professional education and industrial craft training. The division's programs include the Assessment and Field Support Program, the Labor and Policy Studies Program, Professional Training Programs, the Training and Technology Program, and University Programs.

\section{NOTicES}

The opinions expressed herein do not necessarily reflect the opinions of the sponsoring institutions of Oak Ridge Associated Univarsities.

This report was prepared as an account of work sponsored by an agency of the United States Government. Naither the United States Government nor any agency thereof, nor any of their employees, makes any warranty, express or implied, nor assumes any legal liability or responsibility for any third party's use or the results of such use of any information. apparatus, product or process disclosed in this report, nor represents that its use by such third party would not in fringe privately owned rights.

Available from the National Technical Information Service, U.S. Department of Commerce, Springfield, Virginia 22161. Please direct all price inquiries to NTIS. 


\title{
Radiation Protection \\ Enrollments and Degrees, 1979 and 1980
}

July 1981

\author{
Prepared by \\ Ruth M. Gove \\ Joanna R. Little \\ Duveen L. Shirley
}

\author{
Labor and Policy Studies Program \\ Manpower Education, Research, and Training Division \\ Oak Ridge Associated Universities
}

\author{
Prepared for \\ Manpower Assessment Program \\ Advisory and Institutional Coordination Division \\ Office of Energy Research \\ U.S. Department of Energy
}

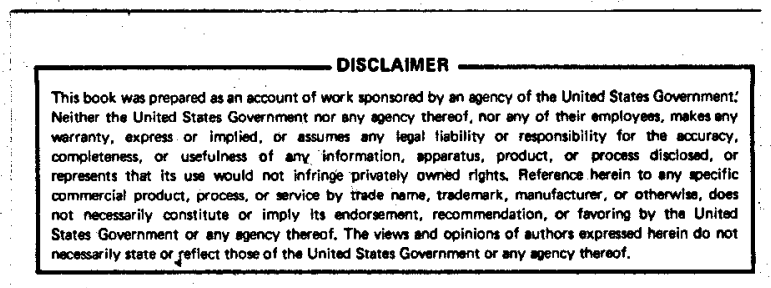

This report is based on work performed under contract number DE-AC05-760R00033 between Oak Ridge Associated Universities and the U.S. Department of Energy. 
Public concern over the effects of low-level radiation and other aspects of the use of nuclear energy has grown in recent years, and the demand for radiation protection has continued to increase. Radiation Protection Enrollments and Degrees presents the results of the latest survey of institutions offering degree programs in this field. Students obtaining such degrees are vital to the development of industry, medicine, research, power production, construction, and agriculture. These surveys assist state and federal governments in their search for such personnel.

On behalf of all who use this document, we thank the individuals and institutions who provided the information. 
TABLE OF CONTENTS

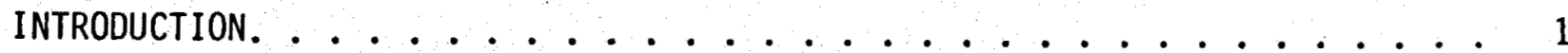

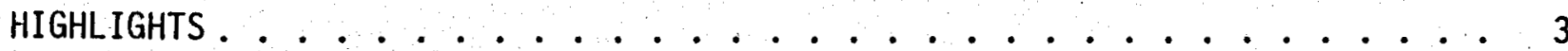

ENROLLMENTS AND DEGREES .................... 5

Doctoral ...................... 5

Master's ...................... 5

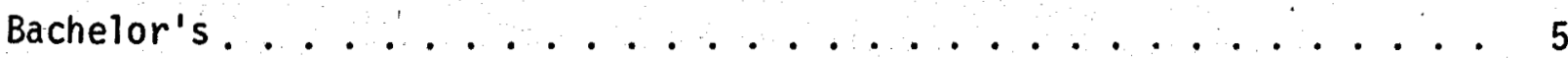

PLACEMENT OF GRADUATES ..................... 9

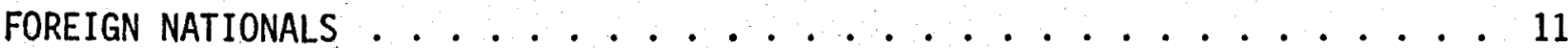

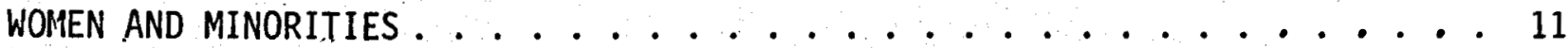

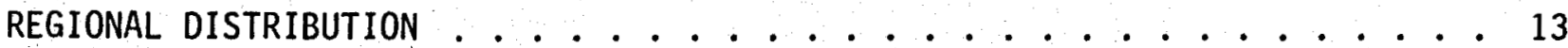

CHART:

1. Degrees Granted in Radiation Protection, 1968-1980 . . . . . . 2

TEXT TABLES:

1. Total Enrollment of Full-Time and Part-Time Students in Radiation Protection by Educational Level, Fall 1973 through

Fall 1980 .................... 6

2. Full-Time and Part-Time Graduate Enrollment and Degrees Granted in Radiation Protection by Subfield . . . . . . . . . . 7

3. Full-Time and Part-Time Undergraduate Enrollment and Bachelor's Degrees Granted in Radiation Protection by Subfield ........ 8

4. Placement of 1979 and 1980 Radiation Protection Graduates by Degree Level ... . . . . . . . . . . . . . 10

5. Participation by Foreign Nationals, Women, and Minorities in Radiation Protection Programs, 1973-1980 .......... 12 


\section{APPENDIXES:}

Appendix A. Statistical Tables

A-1. Radiation Protection Degrees Granted 1970-1980, by Institution . 15

A-2. Radiation Protection Enrollments and Degrees in Subfields

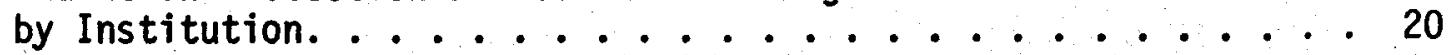

A-3. Foreign Nationals, Women, Minorities: Radiation Protection Enrollments and Degrees by Institution. . . . . . . . 29

A-4. Radiation Protection Curricula or Options by Undergraduate or Graduate Institution, Fall 1980. . . . . . . . . . 38

A-5. Radiation Protection Number of Enrol lments and Degrees by State and Region ............................. 42

Appendix B. Addresses

B-1. Addresses of Institutions in Survey Universe with Active Programs in Radiation Protection, 1980.......... 45

B-2. Addresses of Institutions in Survey Universe with Inactive or Discontinued Programs, in Radiation Protection, 1979 and $1980 \ldots \ldots . \ldots . \ldots 48$

Appendix C. Survey Materials . . . . . . . . . . . . . 49 
This report represents a compilation of data from the ninth and tenth annual surveys of "radiation protection enrollments and degrees." These surveys were completed for the 1978-79 and 1979-80 academic years. Each year the survey is sent to institutions offering degrees in radiation protection and in other closely related fields (health physics, radiation health, radiological physics, radiobiology, and similar programs) whose graduates would be prepared to conduct, coordinate, direct, or plan a program for the evaluation and control of radiation hazards in various settings. The number of institutions that are surveyed may change from year to year as new programs are identified and other programs are discontinued. The 1979 survey revealed four institutions with inactive programs and one institution whose program was closed; however, this program was reopened in 1980. The 1980 survey revealed only three institutions with inactive programs (two of which were inactive in 1979).

Appendix B-1 lists the addresses of institutions with active programs reported in the 1980 survey. Appendix B-2 lists the institutions with inactive and discontinued programs in 1979 and 1980. 


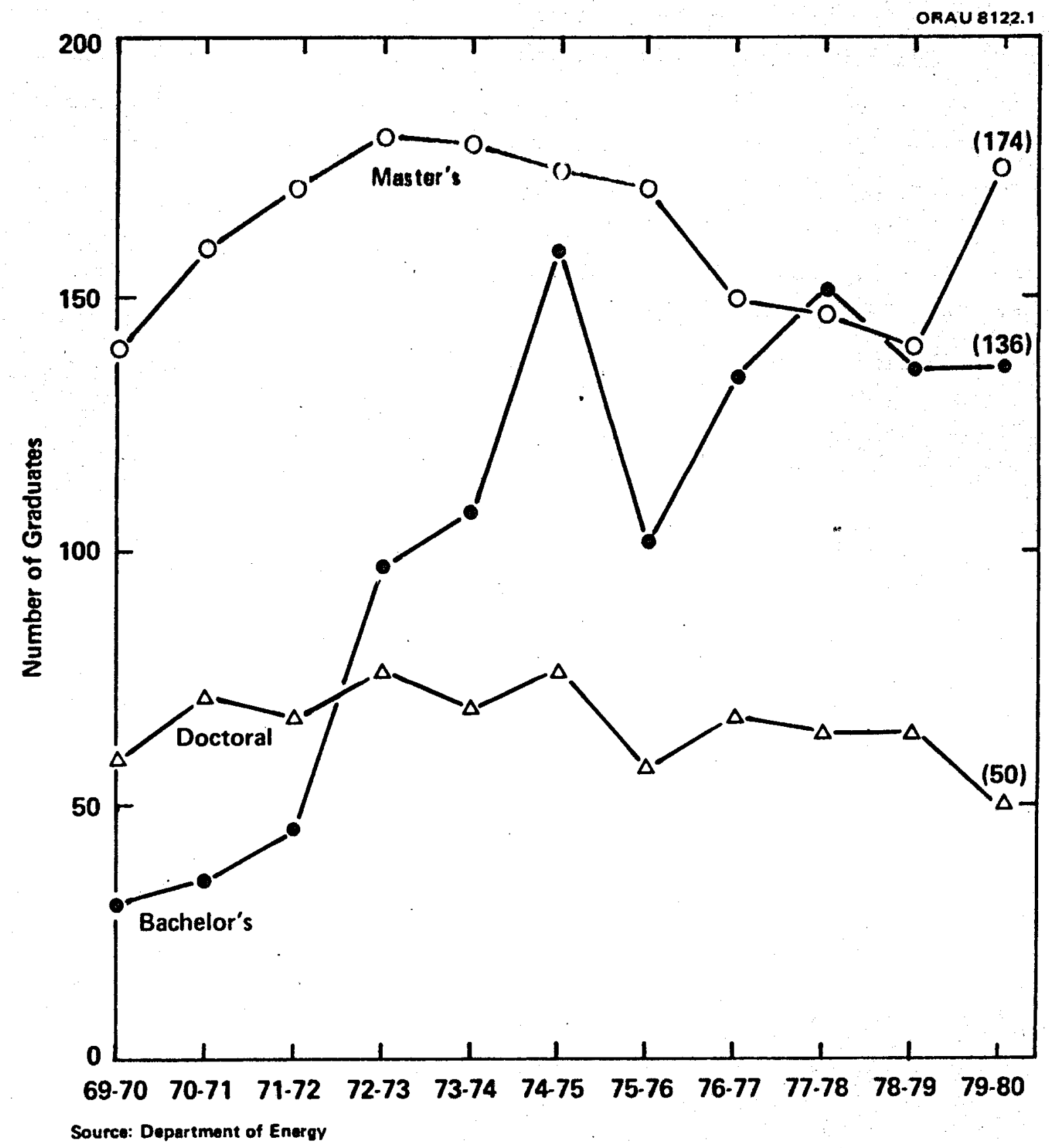

Chart 1. Degrees Granted in Radiation Protection, 1969-80 


\section{HIGHLIGHTS}

\section{SURVEY UNIVERSE}

The 1979 survey included 55 institutions of which 50 reported active programs, 1 reported its program was discontinued, and 4 reported their programs were inactive. The 1980 survey included 55 institutions, and the reports indicated that there were 52 active programs and 3 inactive programs.

\section{ENROLLMENT}

Enrollment decreased by 11 percent at the undergraduate level between 1978 and 1979 and increased between 1979 and 1980 by 30 percent. Master's enrollment remained essentially the same from 1978 through 1980 , varying only 1 or 2 percent. At the doctoral level, an 11 percent decrease occurred between 1978 and 1979 with a slight recovery of 4 percent between 1979 and 1980.

\section{DEGREES AWARDED}

Bachelor's degrees awarded in 1979 and in 1980 were 10 percent below those awarded in 1978. Master's degrees decreased slightly between 1978 and 1979 but rose by 26 percent between 1979 and 1980 . The number of doctorate degrees awarded remained constant at 63 between 1978 and 1979 but decreased 21 percent to 50 in 1980.

\section{PLACEMENT}

Private industry was the largest employer of bachelor's and master's degree holders in 1980, and medical facilities were the largest employers of doctorates.

The percentage of recipients of bachelor's degrees who went on for further study increased 11 points (to 21 percent) from 1978 to 1980 . In 1980, 19 percent of all those receiving master's degrees went on for further study. At the doctoral level, 16 percent were hired by colleges and universities in 1980.

It was difficult to perceive any major placement trends because of the large number of unknown placements at all degree levels. However, one institution reported that it could have placed several more individuals than the number graduating from its program. 
FOREIGN NATIONALS

Foreign national student enrollment has decreased since 1978 at the undergraduate and master's level, while the number of doctoral candidates has increased. Bachelor's and doctoral degrees awarded to foreign nationals decreased somewhat while master's degrees increased slightly.

WOMEN AND MINORITIES

Minority participation in radiation protection programs in 1979 and 1980 remained at about the same percentage of the total as in earlier years. Female student enrollments have increased since 1978, and so has the number of degrees awarded to women.

REGIONAL DISTRIBUTION

Undergraduate enrollment was highest in the Middle Atlantic region, which had 33 percent of the total enrolled during the 1979-1980 academic year. However, the Pacific region contained the largest proportion of graduate students with 25 percent of the total in 1980 . By state, California awarded the largest number of degrees at all levels. 


\section{ENROLLMENTS AND DEGREES}

Total enroliment in 1979 for both undergraduates and graduates declined almost 8 percent in comparison to 1978, and then increased by almost 11 percent in 1980 over 1979, (see Table 1). Approximately one quarter of the respondents listed enrollment in subfields other than those listed on the survey instrument.

DOCTORAL

Doctoral candidate enrollments in the fall of 1980 were 282 fulltime and 35 part-time students. This represents an 8 percent decrease since 1978 in total enrol lment at that level. Fifty doctoral degrees were granted during the academic year ending in June 1980, compared to 63 awarded in 1978 - 21 percent decline; (see Chart 1 and Appendix A-1).

As presented in Table 2, the largest two subfields in doctoral enrollments in 1979 and 1980 were radiobiology or biophysics and medical radiation physics or radiological physics. Approximately two-thirds of the students were enrolled in these programs in the fall of 1979 and 1980. The percentage of degrees awarded was highest, however, during those two years in health physics, radiation health or radiation protection, and radiobiology or biophysics with about 70 percent of the students. MASTER'S

There was a total of 427 master's degree candidates ( 305 ful1-time and 122 part-time) enrolled in the fall of 1980 . This enrollment number has remained about the same since 1978, decreasing only slightly in 1979 (see Table 2).

During the academic year $1979-80,174$ master's degrees were granted, an increase of 19 percent over the number awarded in 1978 and the highest number of degrees awarded in this category since 1974. Of all reporting institutions, 32 , or 57 percent, awarded master's degrees. BACHELOR'S

Total undergraduate enrollment has increased the last two years by 15 percent over fall of 1978 . There were 158 full-time and 99 part-time juniors enrolled in the fall of 1980, while 111 full-time and 43 parttime seniors were enrolled (see Table 3 ). 
TABLE 1

TOTAL ENROLLMENT OF FULL-TIME AND PART-TIME STLDENTS

FALL 1973 THROUGH FALL 1980

\begin{tabular}{|cccccc|}
\hline \multicolumn{7}{c|}{ FALL ENROLLMENT } \\
\cline { 2 - 6 } & JUNIORS & SENIORS & $\begin{array}{c}\text { MASTER'S } \\
\text { CANDIDATES }\end{array}$ & $\begin{array}{c}\text { DOCTORAL } \\
\text { CANDIDATES }\end{array}$ & TOTAL ENROLLMENT \\
\hline 1973 & 110 & 95 & 307 & 351 & 863 \\
1974 & 114 & 121 & 308 & 343 & 886 \\
1975 & 214 & 206 & 411 & 348 & 1179 \\
1976 & 168 & 129 & 399 & 378 & 1074 \\
1977 & 244 & 198 & 407 & 329 & 1178 \\
1978 & 179 & 178 & 428 & 344 & 1129 \\
1979 & 161 & 155 & 421 & 305 & 1042 \\
1980 & 257 & 154 & 427 & 317 & 1155 \\
& & & & & \\
\hline
\end{tabular}

SOURCE: U.S. Department of Energy. 
TABLE 2

FULL-TIME AND PART-TIME GRADUATE ENROLLMENT AND OEGREES GRANTED

IN RADIATION PROTECTION BY SUBFIELD

\begin{tabular}{|c|c|c|c|c|c|c|c|c|c|c|c|c|c|c|c|c|}
\hline \multirow[b]{4}{*}{ SUBFIELOS } & \multicolumn{12}{|c|}{ ENROLLMENT - FALL 1979} & \multicolumn{4}{|c|}{ DEGREES $(1978-79)$} \\
\hline & \multirow{2}{*}{\multicolumn{6}{|c|}{$\begin{array}{c}\text { MASTER'S CANDIDATES } \\
\text { FULL-TIME |PART-TIME IOTAL }\end{array}$}} & \multicolumn{6}{|c|}{$\therefore \quad$ DOCTORAL CANDIDATES } & \multicolumn{2}{|c|}{ MASTER'S } & \multicolumn{2}{|c|}{ DOCTORATES } \\
\hline & & & & & & & \multicolumn{2}{|c|}{ FULL-TIME } & \multicolumn{2}{|c|}{ PART-TINE } & \multicolumn{2}{|c|}{ TOTAL } & & & & \\
\hline & No. & Pct. & No. & Pct. & No. & Pct. & No. & Pct. & No. & Pct. & No. & Pct. & No. $P$ & Pct. & No. & Pct. \\
\hline $\begin{array}{l}\text { Health Physics, Radiation } \\
\text { Health, or Radiation } \\
\text { Protection }\end{array}$ & 123 & 42 & 81 & 66 & 204 & 48 & 40 & 16 & 16 & 34 & 56 & 18 & $72 i$ & 52 & 19 & 30 \\
\hline Radiobiology or Biophysics & 40 & 14 & 2 & 2 & 42 & 10 & 108 & 42 & 3 & 6 & 111 & 36 & $11 i$ & 8 & 23 & 37 \\
\hline $\begin{array}{l}\text { Medical Radiation Physics or } \\
\text { Radiological Physics }\end{array}$ & 90 & 31 & 26 & 21 & 116 & 28 & 74 & 29 & 16 & 34 & 90 & 30 & $34 !$ & 25 & 14 & 22 \\
\hline $\begin{array}{l}\text { Engineering or Basic Sciences, } \\
\text { Health Physics Option }\end{array}$ & 7 & 2 & 0 & 0 & 7 & 2 & 1 & 0 & 1 & 2 & 2 & 1 & 3 & 2 & 0 & 0 \\
\hline Other (Specify those not listed) & 39 & 13 & 13 & 11 & 52 & 12 & 35 & 14 & 11 & 23 & 46 & 15 & 18 & 13 & 7 & 11 \\
\hline
\end{tabular}

\begin{tabular}{|c|c|c|c|c|c|c|c|c|c|c|c|c|c|c|c|c|}
\hline TOTALS & 299 & & 122 & & 421 & & 258 & & 47 & & 305 & & 138 & & 63 & \\
\hline \multirow[b]{4}{*}{ SUBFIELDS } & \multicolumn{12}{|c|}{ ENROLLMENT - FALL 1980} & \multicolumn{4}{|c|}{ DEGREES $(1979-80)$} \\
\hline & \multirow{2}{*}{\multicolumn{6}{|c|}{$\begin{array}{c}\text { MASTER'S CANDIDATES } \\
\text { FUITIME }\end{array}$}} & \multicolumn{6}{|c|}{ DOCTORAL CANDIDATES } & \multicolumn{2}{|c|}{ MASTER'S } & \multicolumn{2}{|c|}{ DOCTORATES } \\
\hline & & FULL-TIME & \multicolumn{2}{|c|}{ PART-TIME } & & & \multicolumn{2}{|c|}{ FULL-TIME } & \multicolumn{2}{|c|}{ PART-TIME } & \multicolumn{2}{|c|}{ TOTAL } & \multirow{2}{*}{\multicolumn{2}{|c|}{ No. Pct. }} & \multirow[b]{2}{*}{ No. } & \multirow[b]{2}{*}{ Pct. } \\
\hline & No. & Pct. & No. & Pet. & No. & Pct. & No. & Pct. & No. & Pct. & No. & Pct. & & & & \\
\hline $\begin{array}{l}\text { Health Physics, Radiation } \\
\text { Health, or Radiation } \\
\text { Protection }\end{array}$ & 151 & 50 & 96 & 79 & 247 & 58 & 48 & 17 & 12 & 34 & 60 & 19 & 99 & 57 & 13 & 26 \\
\hline Radiobiology or Biophysics & 32 & 10 & 4 & 3 & 36 & 8 & 123 & 44 & 1 & 3 & 124 & 39 & 19 & 11 & 23 & 46 \\
\hline $\begin{array}{l}\text { Medical Radiation Physics or } \\
\text { Radiological Physics }\end{array}$ & 87 & 29 & 20 & 16 & 107 & 25 & 77 & 27 & 11 & 31 & 88 & 28 & 35 & 20 & 10 & 20 \\
\hline $\begin{array}{l}\text { Engineering or Basic Sciences, } \\
\text { Health Physics Option }\end{array}$ & 10 & 3 & 0 & 0 & 10 & 2 & 2 & 1 & 0 & 0 & 2 & 1 & 1 & 1 & 1 & 2 \\
\hline Other (Specify those not listed) & 25 & 8. & 2 & 2 & 27 & 6 & 32 & 11 & 11 & 31 & 43 & 14 & 20 & 12 & 3 & 6 \\
\hline TOTALS & 305 & & 122 & & 427 & & 28 & & 35 & & 317 & & 174 & & 50 & \\
\hline
\end{tabular}

NOTE: Percentages may not add to 100 because of rounding.

SOURCE: U.S. Department of Energy. 
TABLE 3

FULL-TIME AND PART-TIME UNDERGRADUATE ENROLLMENT AND BACHELOR'S DEGREES GRANTED IN RADIATION PROTECTION BY SUBFIELD

\begin{tabular}{|c|c|c|c|c|c|c|c|c|c|c|c|c|c|c|}
\hline \multirow[b]{4}{*}{ SUBFIELDS } & \multicolumn{12}{|c|}{ ENROLLMENT - FALL 1979} & \multirow{3}{*}{\multicolumn{2}{|c|}{$\begin{array}{l}\text { BACHELOR'S } \\
\text { DEGREES } \\
1978-79\end{array}$}} \\
\hline & \multicolumn{6}{|c|}{ JUNIORS } & \multicolumn{6}{|c|}{ SENIORS } & & \\
\hline & \multicolumn{2}{|c|}{ FULL-TIME } & \multicolumn{2}{|c|}{ PART-TIME } & \multicolumn{2}{|c|}{ TOTAL } & \multicolumn{2}{|c|}{ FULL-TIME } & \multicolumn{2}{|c|}{ PART-TIME } & \multicolumn{2}{|c|}{ TOTAL } & & \\
\hline & No. & Pct. & No. & Pct. & No. & Pct. & No. & Pct. & No. & Pct. & No. & Pct. & No. & Pct. \\
\hline $\begin{array}{l}\text { Health Physics, Radiation } \\
\text { Health, or Radiation } \\
\text { Protection }\end{array}$ & 55 & 46 & 1 & 2 & 56 & 35 & 83 & 73 & 2 & 5 & 85 & 55 & 70 & 51 \\
\hline Radiobiology or Biophysics & 50 & 42 & 0 & 0 & 50 & 31 & 21 & 18 & 0 & 0 & 21 & 14 & 20 & 15 \\
\hline $\begin{array}{l}\text { Medical Radiation Physics or } \\
\text { Radiological Physcis }\end{array}$ & 2 & 2 & 1 & 2 & 3 & 2 & 0 & 0 & 2 & 5 & 2 & 1 & 0 & 0 \\
\hline $\begin{array}{l}\text { Engineering or Basic Sciences, } \\
\text { Health Physics Option }\end{array}$ & 2 & 2 & 1 & 2 & 3 & 2 & 3 & 3 & 4 & 10 & 7 & 5 & 6 & 4 \\
\hline Other (Specify those not listed) & 10 & 8 & 39 & 93 & 49 & 30 & 7 & 6 & 33 & 80 & 40 & 26 & 40 & 29 \\
\hline
\end{tabular}

TOTALS

119

42

161

114

41

155

136

\begin{tabular}{|c|c|c|c|c|c|c|c|c|c|c|c|c|c|c|}
\hline \multirow[b]{4}{*}{ SUBFIELDS } & \multicolumn{12}{|c|}{ ENROLLMENT - FALL 1980} & \multirow{3}{*}{\multicolumn{2}{|c|}{$\begin{array}{l}\text { BACHELOR'S } \\
\text { DEGREES } \\
1979-80\end{array}$}} \\
\hline & \multicolumn{6}{|c|}{ JUNIORS } & \multicolumn{6}{|c|}{ SENIORS } & & \\
\hline & \multicolumn{2}{|c|}{ FULL-TIME } & \multicolumn{2}{|c|}{ PART-TIME } & \multicolumn{2}{|c|}{ TOTAL } & \multicolumn{2}{|c|}{ FULL-TIME } & \multicolumn{2}{|c|}{ PART-TIME } & \multicolumn{2}{|c|}{ TOTAL } & & \\
\hline & No. & Pct. & No. & Pct. & No. & Pct. & No. & Pct. & No. & Pct. & No. & Pct. & No. & Pct. \\
\hline $\begin{array}{l}\text { Health Physics, Radiation } \\
\text { Health, or Radiation } \\
\text { Protection }\end{array}$ & 52 & 33 & 2 & 2 & 54 & 21 & 64 & 58 & 0 & 0 & 64 & 42 & 65 & 48 \\
\hline Radiobiology or Biophysics & 73 & 46 & 0 & 0 & 73 & 28 & 35 & 32 & 0 & 0 & 35 & 23 & 33 & 24 \\
\hline $\begin{array}{l}\text { Medical Radiation Physics or } \\
\text { Radiological Physics }\end{array}$ & 24 & 15 & 0 & 0 & 24 & 9 & 0 & 0 & 0 & 0 & 0 & 0 & 0 & 0 \\
\hline $\begin{array}{l}\text { Engineering or Basic Sciences, } \\
\text { Heal th Physics Option }\end{array}$ & 2 & 1 & 6 & 6 & 8 & 3 & 1 & 1 & 4 & 9 & 5 & 3 & 3 & 2 \\
\hline Other (Specify those not listed) & 7 & 4 & 91 & 92 & 98 & 38 & 11 & 10 & 39 & 91 & 50 & 32 & 35 & 26 \\
\hline
\end{tabular}

NOTE: Percentages may not add to 100 because of rounding. -

SOURCE: U.S. Department of Energy 
One hundred thirty-six bachelor's degrees were granted during the academic year ending June 1980 which is 10 percent fewer than in 1978. The subfield category of health physics, radiation health, or radiation protection continued to be the largest area of enrollment over the past two years. The percentage of degrees granted in this area has remained about the same, declining only two percentage points since 1978.

\section{PLACEMENT OF GRADUATES}

New doctorate holders found employment most often in academic institutions or medical facilitites, as in past years. The academic institution absorbed 11 percent in 1979 and 16 percent in 1980, while medical facilities employed 17 percent in 1979 and 20 percent in 1980. Government-owned, contractor-operated facilities took five new doctorates in each of the last three years. All other placement categories varied a few percentage points. Only one doctoral graduate was reported to be still seeking employment in the 1979 survey, which implies a continuing strong demand for doctorates in radiation protection. From the 55 institutions surveyed in 1980,11 doctoral graduates were reported as placement unknown, making it difficult to portray any major placement trends.

As shown in Table 4, the proportions of master's graduates who elected to continue their studies in 1979 and 1980 were 23 percent and 19 percent respectively, compared to 22 percent in 1978 . Medical facilities and private industry continue to take a sizable proportion of master's degree recipients, with a higher percentage going to private industry in 1980 than in previous years, and medical facility placement remaining about the same. Placement in the military decreased in 1980 to 2 percent from the 5 percent reported in 1978 and 1979. Only two persons in 1979 and one in 1980 were reported as still seeking employment; al though a sizable number were reported as placement unknown (14 percent in 1979 and 10 percent in 1980).

Placement of new bachelor's degree holders was divided mainly into three categories: further study with 11 percent in 1979 and 21 percent in 1980, medical facilities with 16 percent in 1979 and 23 percent in 1980, and U.S. industry with 23 percent in 1979 and 29 percent in 1980 . These 
TABLE 4

PLACEMENT OF 1979 AND 1980 RADIATION

PROTECTION GRADUATES BY DEGREE LEVEL

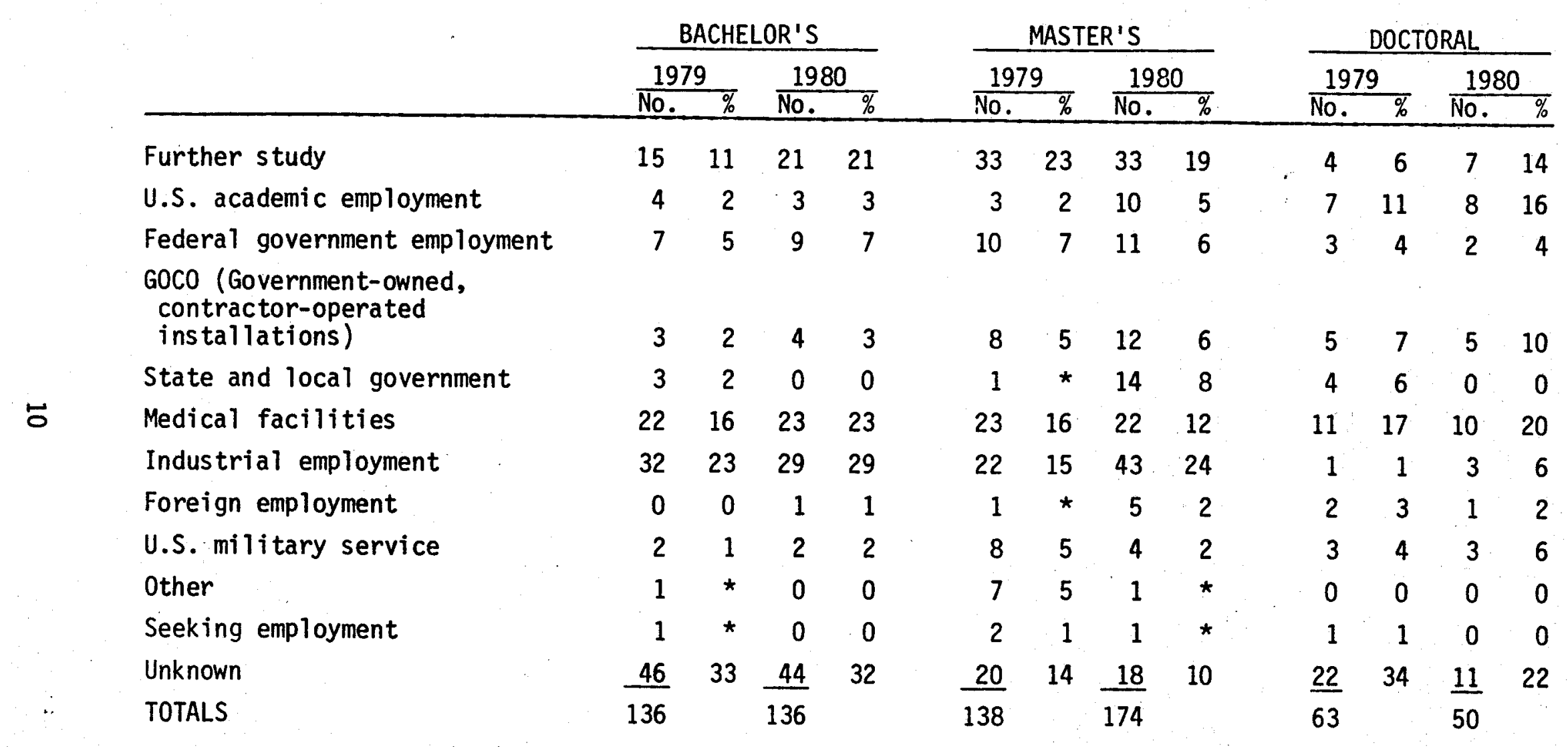

*Less than 1 percent.

SOURCE: U.S. Department of Energy. 
percentages remain about the same as in 1978 although a slight decrease in industry placement has been reported since 1978. Only one bachelor's degree holder was reported as still seeking employment in 1979 and none in 1980. However, 33 percent in 1979 and 32 percent in 1980 were reported as placement unknown, which makes it difficult to portray any major placement trends.

\section{FOREIGN NATIONALS}

Enrollment of foreign nationals changed only slightly in 1979, and no juniors were enrolled in 1980. In 1980, doctoral candidates increased three percentage points over the previous two years. Only a total of four bachelor's degrees were granted to foreign nationals in the last two years. The number granted master's degrees increased by five in 1980, but the number receiving doctorates remained about the same as in 1978 and 1979 (see Table 5).

\section{WOMEN AND MINORITIES}

Enroliment of women increased significantly in the last two years at most levels as shown in Table 5. Third-year female enrollment increased to 35 percent of the total in 1980; senior enrollment accounted for 30 percent; female master's candidates rose to 22 percent; and doctoral candidates rose to 21 percent in 1980. There was a significant increase in bachelor's degrees awarded to women in the last two years. Thirtyfour percent of the bachelor's degrees awarded in 1979 and 30 percent in 1980 went to women. Twenty-five percent of the master's degrees awarded in 1979 and 16 percent in 1980 went to women, a slight increase over 1978. Doctoral degrees granted to women increased from 11 percent in 1978 to 15 percent in 1979 and 18 percent in 1980.

Participation by blacks generally decreased in 1979 and 1980. Exceptions were enrolled juniors and master's candidates. Blacks earned 7 percent of the bachelor's degrees awarded in 1979 and 5 percent in 1980, down from 13 percent in 1978. The number of master's degrees awarded to blacks steadily decreased from 1978, with two in 1979 and one in 1980. There were no doctoral degrees awarded to blacks in 1980, making a total of three for the last three years. 
TABLE 5

PARTICIPATION BY FOREIGN NATIONALS, HOMEN, AND MINORITIES

IN RADIATION PROTECTION PROGRAMS

1973-1980

ENROLLMENTS (FALL TERM)

Junior Senior Candidates Candidates

No. $\%$ No. $\%$ No. $\%$ No. $\%$

FOREIGN NATIONALS

1973

1974

1975

1976

1977

1978

1979

1980

WOMEN

1973

1974

1975

1976

1977

1978

1979

1980

BLACKS

1973

1974

1975

1976

1977

1978

1979

1980

HISPANIC U.S. CITIZENS

1973

1974

1975

1976

1977

1978

1979

1980

ASIAN AMERICANS

\section{PACIFIC ISLANDERS}

1973
1974
1975
1976
1977
1978
1979
1980

AMERICAN INDIANS

$\begin{array}{rrrrrrrr}3 & 3 & 6 & 6 & 29 & 9 & 33 & 9 \\ - & - & 5 & 4 & 21 & 7 & 32 & 9 \\ 4 & 2 & 2 & 1 & 33 & 8 & 31 & 9 \\ 6 & 4 & 4 & 3 & 26 & 7 & 47 & 12 \\ 3 & 1 & 1 & \star & 28 & 7 & 39 & 12 \\ 9 & 8 & 1 & 1 & 37 & 11 & 43 & 18 \\ 6 & 6 & 3 & 2 & 36 & 9 & 54 & 18 \\ 0 & 0 & 3 & 2 & 36 & 8 & 62 & 21\end{array}$

DEGREES GRANTED

(YEAR ENDING JUNE 30 )

Bachelor's Master's Doctoral
No. \% No. \% No. \%

$\begin{array}{rrrrrrr}1 & 2 & 8 & 5 & 4 & 6 \\ - & - & 9 & 6 & 3 & 5 \\ 4 & 2 & 12 & 7 & 8 & 10 \\ 1 & 1 & 19 & 11 & 4 & 7 \\ - & - & 16 & 11 & 8 & 12 \\ 4 & 4 & 12 & 11 & 7 & 16 \\ 2 & 2 & 16 & 14 & 6 & 10 \\ 2 & 1 & 21 & 12 & 7 & 14\end{array}$

$\begin{array}{rrrrrr}5 & 8 & 9 & 6 & 3 & 4 \\ 7 & 12 & 9 & 7 & 4 & 7 \\ 15 & 9 & 12 & 7 & 5 & 7 \\ 12 & 10 & 18 & 11 & 11 & 20 \\ 22 & 17 & 19 & 13 & 4 & 6 \\ 26 & 25 & 18 & 16 & 5 & 11 \\ 44 & 34 & 29 & 25 & 9 & 15 \\ 41 & 30 & 28 & 16 & 9 & 18\end{array}$

$\begin{array}{rrrr}18 & 16 & 3 & 3 \\ - & - & 1 & 1 \\ 18 & 8 & 17 & 9 \\ 8 & 5 & 2 & 2 \\ 21 & 9 & 17 & 9 \\ 13 & 12 & 13 & 10 \\ 10 & 10 & 9 & 7 \\ 21 & 8 & 9 & 6\end{array}$

$\begin{array}{ll}4 & 1 \\ 2 & 1 \\ 1 & 1 \\ 5 & 1 \\ 5 & 1 \\ 3 & 1 \\ 7 & 2 \\ 9 & 2\end{array}$

$\begin{array}{ll}2 & 1 \\ - & - \\ - & - \\ 3 & 1 \\ 4 & 1 \\ 5 & 2 \\ 2 & 1\end{array}$

$\begin{array}{rr}- & - \\ - & - \\ 3 & 3 \\ 9 & 7 \\ 13 & 13 \\ 9 & 7 \\ 7 & 5\end{array}$

$\begin{array}{llll}1 & 1 & 2 & 3 \\ 1 & 1 & 1 & 2 \\ 2 & 1 & 1 & 1 \\ 2 & 1 & - & - \\ 1 & 1 & - & - \\ 4 & 4 & 2 & 4 \\ 2 & 2 & 1 & 2 \\ 1 & 1 & - & -\end{array}$

$\begin{array}{rrrrrrrr}6 & 5 & 1 & 1 & 5 & 2 & 2 & 1 \\ -5 & - & - & - & 8 & 3 & 2 & 1 \\ - & 2 & 4 & 2 & 5 & 1 & 2 & 1 \\ 11 & - & 2 & 2 & 4 & 1 & 4 & 1 \\ 5 & 5 & 2 & 1 & 2 & \star & 5 & 1 \\ 9 & 9 & 2 & 2 & 6 & 1 & 4 & 2 \\ 12 & 5 & 7 & 5 & 7 & 2 & 5 & 2 \\ & & & & & & & 1\end{array}$

$\begin{array}{llllll}- & - & - & - & 1 & 1 \\ 1 & 2 & 4 & 3 & 1 & 2 \\ - & - & 1 & 1 & - & - \\ - & - & 1 & 1 & 2 & 4 \\ 2 & 1 & 1 & 1 & 1 & 2 \\ 3 & 3 & 1 & 1 & - & - \\ 4 & 3 & - & - & - & - \\ 2 & 1 & 3 & 2 & 1 & 2\end{array}$
ALASKAN NATIVES

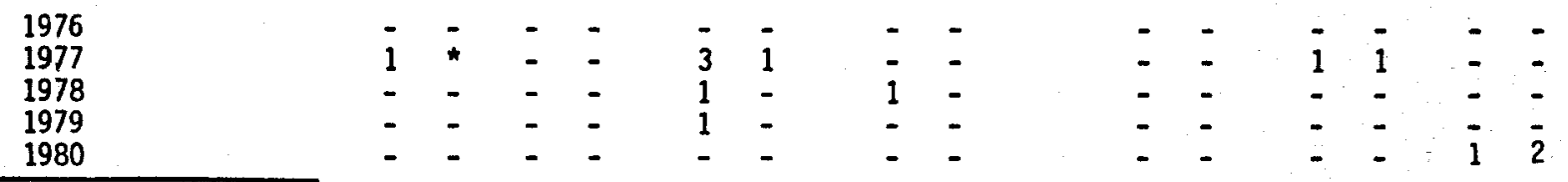

*Less than 0.5 percent.

NOTE: Percentages of enrollment and degrees are based on total enrollment and degrees granted by all institutions reporting in that year.

Source: J.S. Departinent of Energy. 
Enrollment of Asians and Pacific Islanders increased significantly for juniors and seniors in 1980, with only a slight change in master's and doctoral candidates. This group received no bachelor's degrees in 1980 and only one in 1979. There were four master's recipients in 1979 and two in 1980. One doctoral degree was awarded to an Asian/Pacific Islander in 1980 after none had been given in the two prior years.

\section{REGIONAL DISTRIBUTION}

The Middle Atlantic region contains the largest proportion of enrolled undergraduates with 133 juniors and seniors (32 percent of total), and New York alone accounted for 129 in 1980. However, most of those reported were part-time students enrolled at Manhattan Collége. The Pacific region reported the highest number of undergraduates for 1979 (28 percent of total). Indiana had the largest number of full-time undergraduates with 73 in 1980, while California with 56 had the largest in 1979. The regions reporting the largest number of bachelor's degrees awarded in 1980 were the Middle Atlantic with 29 (21 percent of total) and the Pacific with 23 (17 percent of total) in 1979. (See Appendix A-5.)

The region reporting the largest graduate student enrollment in 1979 and 1980 was the Pacific region with 169 (23 percent) and 183 (25 percent), respectively, with california the leading state in both years.

The four states that produced the most master's degrees for 1980 were California (25), Colorado and Georgia (13 each), and Massachusetts (14); while for 1979 the three leading states were California (17), Georgia (15), and Indiana (14). At the doctoral level, California was again the leading state with 20 in 1979 and 14 in 1980, while Florida and Indiana were second in 1979, and New York and Indiana second in 1980. 


\section{APPENDIXES}

\section{Appendix A. Statistical Tables}

\section{Appendix B. Addresses}

Appendix C. Survey Materials 
RADIATION PROTECTION

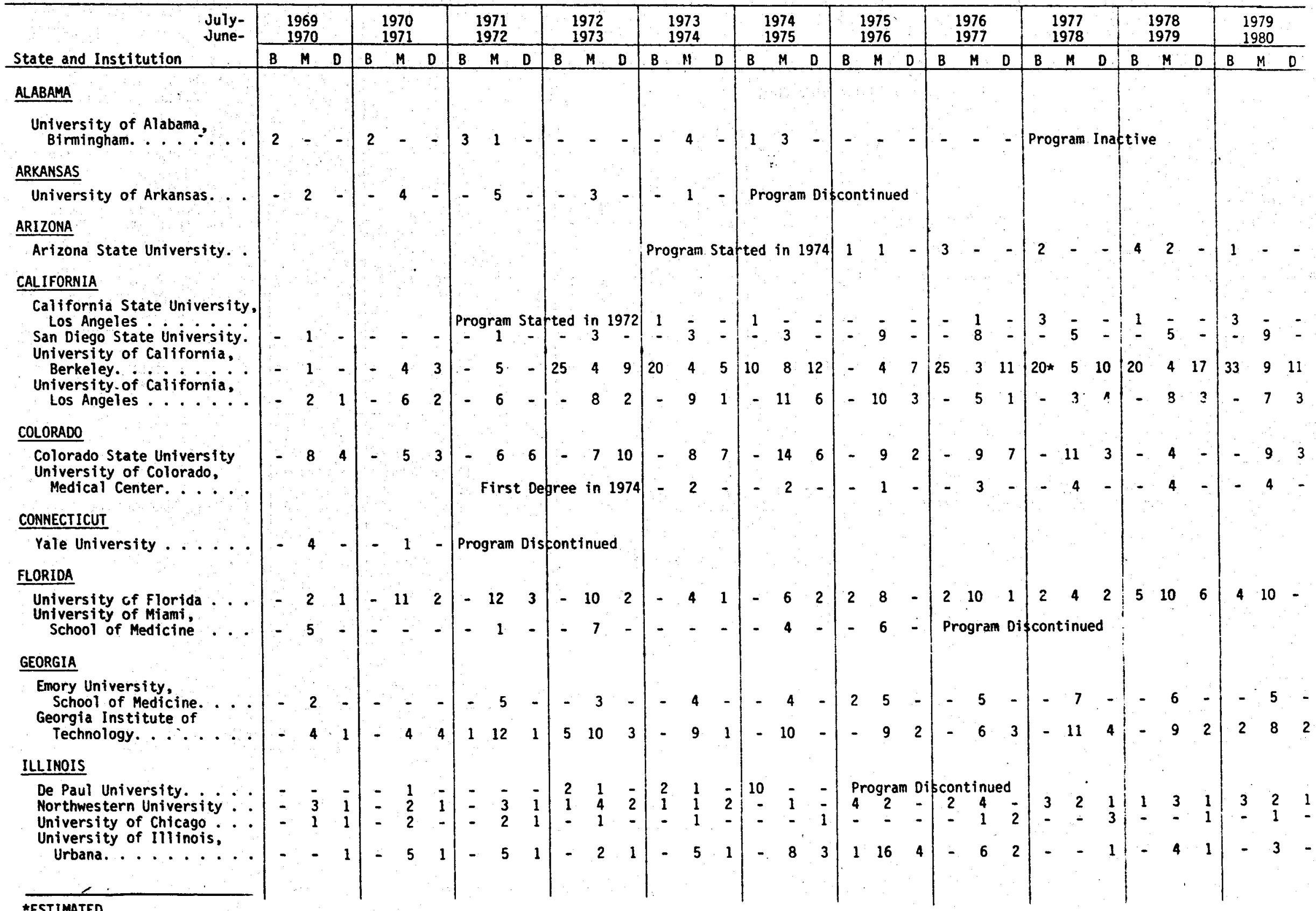


APPENDIX A-1 (Continued)

RADIATION PROTECTION

$B=$ Bachelor's

$M=$ Master's

DEGREES GRANTED 1970-1980, BY INSTITUTION

$D=$ Doctoral

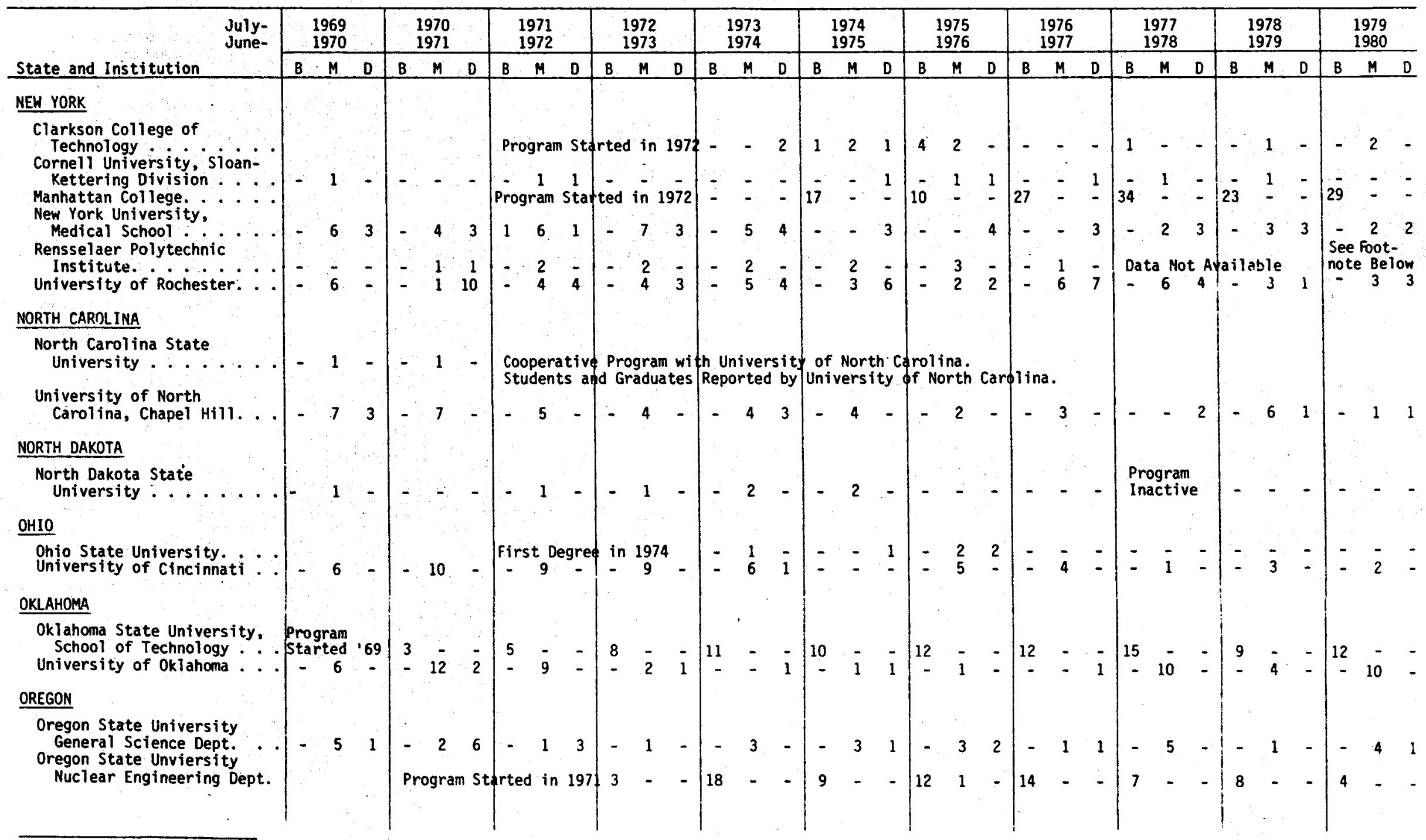

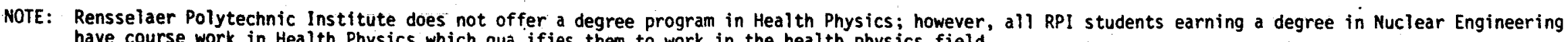
have course work in Health Physics which qua ifies them to work in the health physics field. 


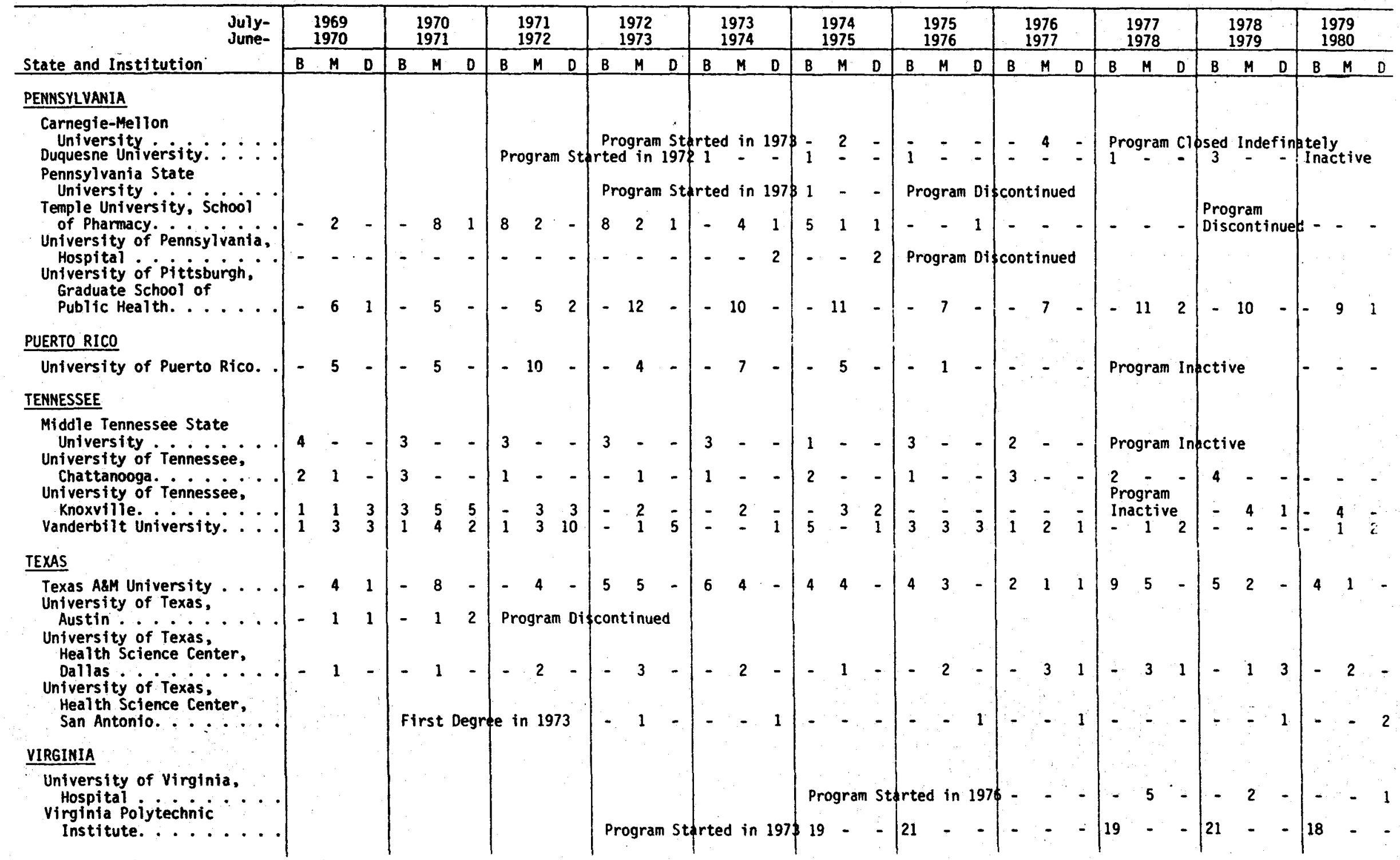


APPENDIX A-1 (Continued)

RADIATION PROTECTION

$8=$ Bachelor's

DEGREES GRANTED 1970-1980, BY INSTITUTION

$M=$ Master's

$D=$ Doctoral

\begin{tabular}{|c|c|c|c|c|c|c|c|c|c|c|c|c|c|c|c|c|c|c|c|c|c|c|c|c|c|c|c|c|c|c|c|c|c|}
\hline \multirow{2}{*}{ State and Institution $\begin{array}{l}\text { July- } \\
\text { June- }\end{array}$} & \multicolumn{3}{|c|}{$\begin{array}{l}1969 \\
1970 \\
\end{array}$} & \multicolumn{3}{|c|}{$\begin{array}{l}1970 \\
1971 \\
\end{array}$} & \multicolumn{3}{|c|}{$\begin{array}{l}1971 \\
1972 \\
\end{array}$} & \multicolumn{3}{|c|}{$\begin{array}{l}1972 \\
1973 \\
\end{array}$} & \multicolumn{3}{|c|}{$\begin{array}{l}1973 \\
1974 \\
\end{array}$} & \multicolumn{3}{|c|}{$\begin{array}{l}1974 \\
1975 \\
\end{array}$} & \multicolumn{3}{|c|}{$\begin{array}{l}1975 \\
1976 \\
\end{array}$} & \multicolumn{3}{|c|}{$\begin{array}{l}1976 \\
1977 \\
\end{array}$} & \multicolumn{3}{|c|}{$\begin{array}{l}1977 \\
1978 \\
\end{array}$} & \multicolumn{3}{|c|}{$\begin{array}{l}1978 \\
1979 \\
\end{array}$} & \multicolumn{3}{|c|}{$\begin{array}{l}1979 \\
1980\end{array}$} \\
\hline & B & M & D & B & $M$ & D & B & $M$ & D & B & $M$ & D & B & $M$ & 0 & $\mathrm{~B}$ & $M$ & D & $\mathrm{B}$ & $M$ & 0 & B & $M$ & $D$ & B & $M$ & D & $B$ & $M$ & D & B & $M$ & D \\
\hline WASHINGTON & & & & & & & & & & & & & & & & & & & & & & & & & & & & & & & & & \\
\hline University of Washington . . & - & 4 & - & - & - & - & - & 5 & - & - & 1 & 1 & - & 3 & - & - & 3 & - & - & 3 & - & - & 4 & - & - & - & - & - & 1 & - & - & 1 & - \\
\hline WISCONSIN & & & & & & & & & & & & & & & & & & & & & & & & & & & & & & & & & \\
\hline $\begin{array}{l}\text { University of Wisconsin, } \\
\text { Madison. }\end{array}$ & - & - & 2 & - & 2 & 2 & - & 3 & 5 & - & 4 & 2 & - & 4 & 1 & - & 6 & 4 & - & 6 & 2 & & 5 & - & - & - & - & $=$ & 3 & 2 & $=$ & 6 & 3 \\
\hline TOTALS & 31 & 141 & 58 & 35 & 15 & 71 & 46 & 17 & 67 & 97 & 18 & 76 & 11 & 179 & 67 & 159 & 174 & 77 & 11 & 171 & 57 & 133 & 148 & 67 & 151 & 146 & 63 & 131 & 138 & 63 & 13 & 174 & 50 \\
\hline
\end{tabular}


APPENDIX A-2

RADIATION PROTECTION

ENROLLMENTS AND DEGREES IN SUBFIELDS BY INSTITUTION

FT $=$ FULL TIME

PT = PART TIME

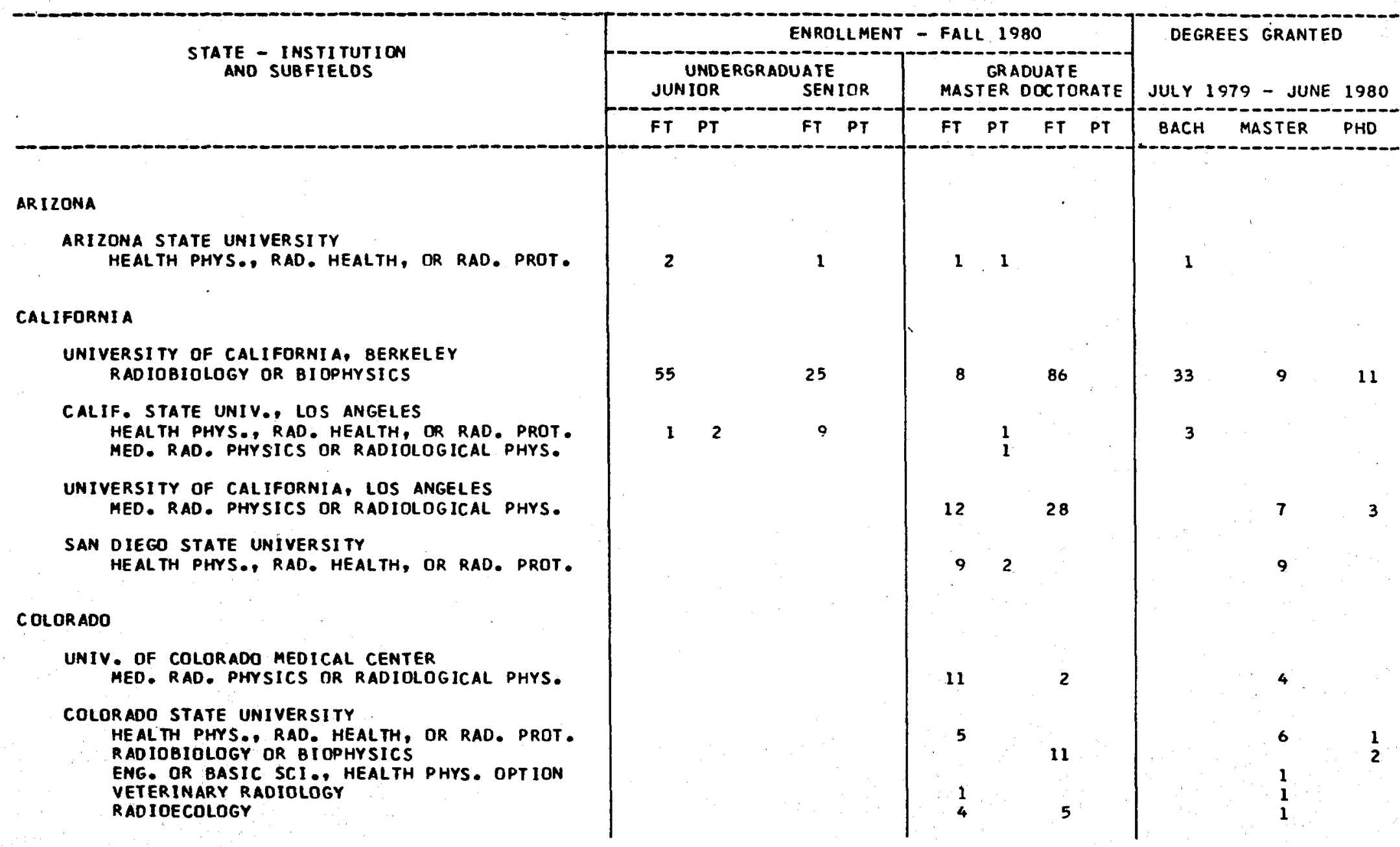




\section{APPENDIX A-2 (Continued) \\ RADIATION PROTECTION}

ENROLLMENTS AND DEGREES IN SUBFIELDS BY INSTITUTION

T = FULL TIME

PT $=$ PART TIME

STATE _ INSTITUTION
AND SUBFIELOS

GI A INSTI TUTE OF TECHNOLOG

DEALTH, OR RAD. PROT MED. RAD. PHYSICS OR RADIOLOGICAL PHYS.

\section{RG I A}

UN UVER SI TY

HEAL TH PHYS., RAD HEALTH, OR RAD. PROT

UNIVERSITY OF CHICAGO

HEALTH, OR RAD. PROT

NGINEERING OPTION 
APPENDIX A-2 (Continued)

RADIATION PROTECTION.

ENROLLMENTS AND DEGREES IN SUBFIELDS BY INSTITUTION

T $=$ FULL TIME

PT = PART TIME

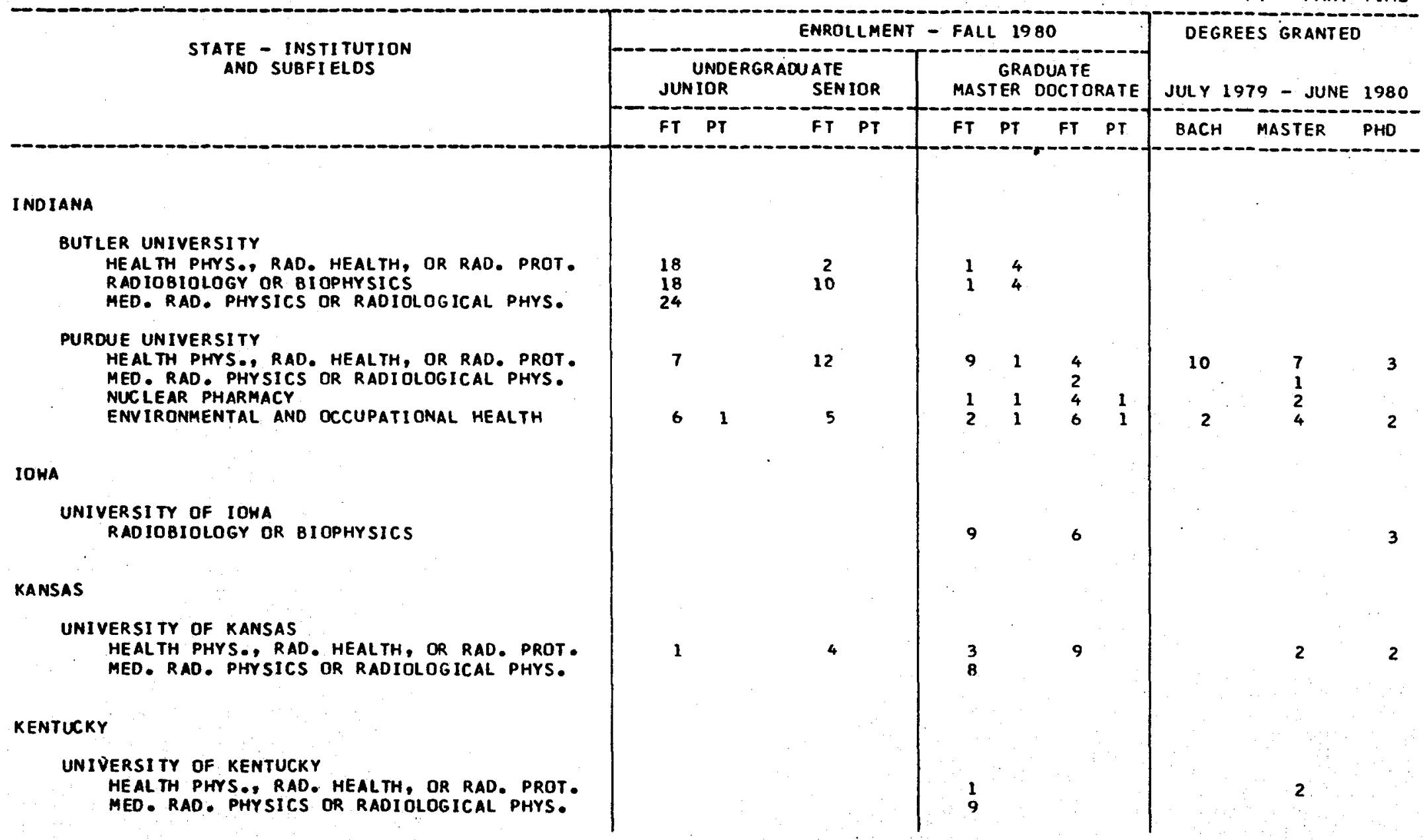


APPENDIX A-2 (Continued)

RADIATION PROTECTION

ENROLLMENTS AND DEGREES IN SUBFIELDS BY INSTITUTION

FT = FULL TIME

PT = PART TIME

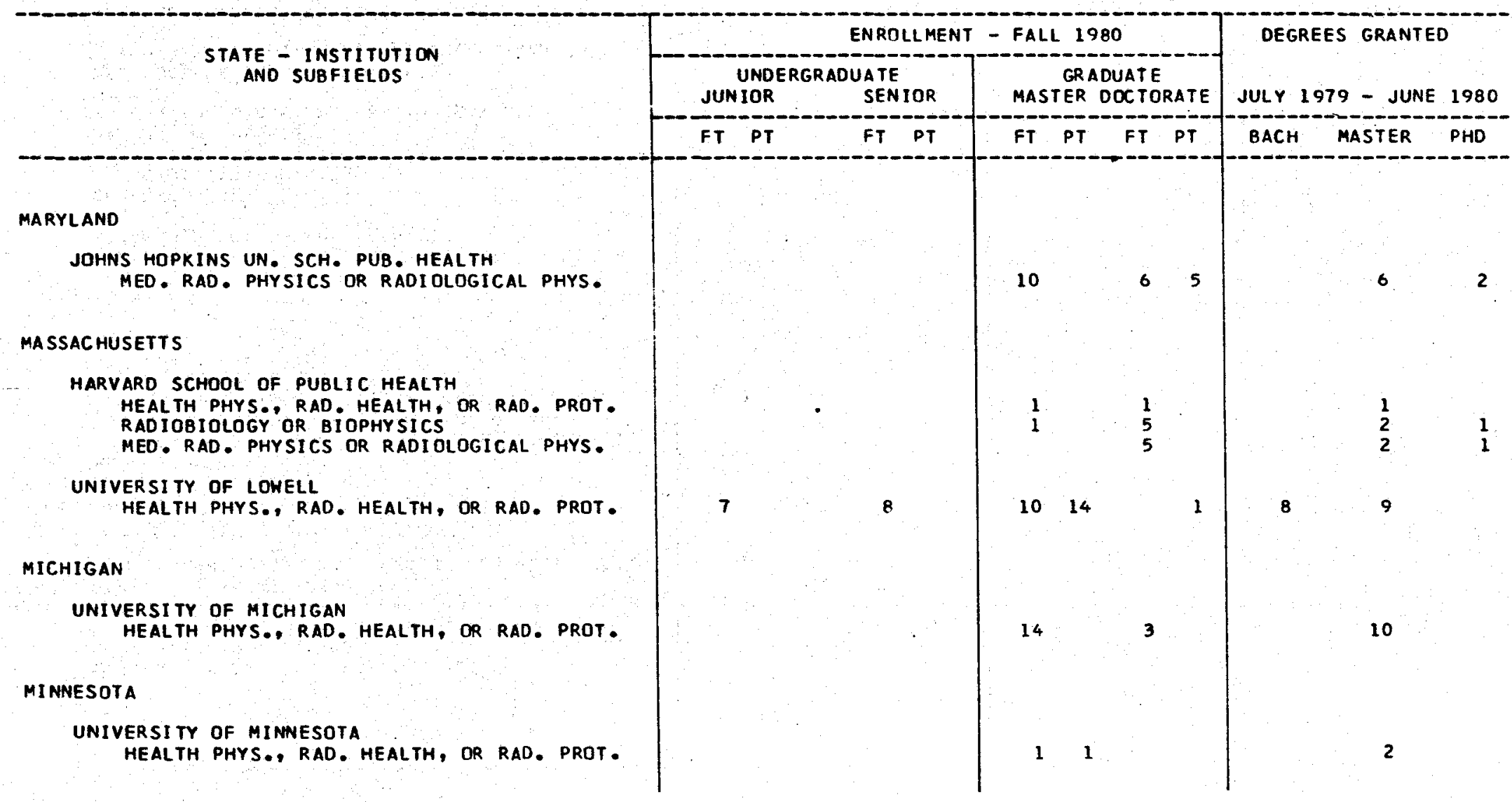

HEALTH PHYS RAD. HEALTH, OR RAD. PROT RADIOBIOLOGY OR BIOPHYSICS

HEALTH PHYS., RAD. HEALTH, OR RAD. PROT

VERSITY OF MICHIGAN

HEALTH PHYS., RAD. HEALTH, OR RAD. PROT.

ERSITY OF MINNESOTA

HEALTH PHYS., RAD. HEALTH, OR RAD. PROT. 
APPENDIX A-2 (Continued)

RADIATION PROTECTION

ENROLLMENTS AND DEGREES IN SUBFIELDS BY INSTITUTION $\quad$ FT = FULL TIME

PT = PART TIME

STATE - INSTITUTION
AND SUBFIELDS
UNIVERSITY OF MISSOURI COLUMBIA
HEALTH PHYS O RAD HEALTH, OR RAO. PROT.
MED. RAD. PHYSICS OR RADIOLOGICAL PHYS.
SAINT LOUIS UNIYERSITY
HEAL TH PHYS., RAD. HEALTH, OR RAD. PROT.

NEW JERSEY
RUTGERS UNIVERSITY

HEALTH PHYS., RAD. HEALTH, OR RAD. PROT MED. RAD. PHYSICS OR RADIOLOGICAL PHYS. ENG. OR BASIC SCI., HEALTH PHYS. OPTION RADIATION CHEMISTRY AEROSOL PHYSICS

NEW YORK

CORNELL UNIVERSITY, SLOAN-KETTERING DIVISION RADIOBIOLOGY OR BIOPHYSICS RADIATION PHYSICS

manHatTAN COLLEGE

RADIOLDGICAL AND HEALTH SCIENCES

NEH YORK UNIV MEDICAL CENTER

MEALTH PHYS., RAD. HEALTH, OR RAD. PROT.

\section{CLARKSON COLLEGE}

- rensselaer polytechinic institute

JUNIOR

[11]
$6 \quad 25$ MASTER DOCTORATE

FT PT FT PT $B A C H$ MASTER PHO

*RPI does not offer a degree program in Health Physics; however, all students earning a degree in Nuclear Engineering have course work in Health Physics which qualifies them to work in the health physics field. Enrollments and degrees are listed above but are not added to the total enrollements and degrees. 
APPENDIX A-2 (Continued)

RADIATION PROTECTION

ENROLLMENTS AND DEGREES IN SUBFIELDS BY INSTITUTION

FT $=$ FULL TIME

PT = PART TIME

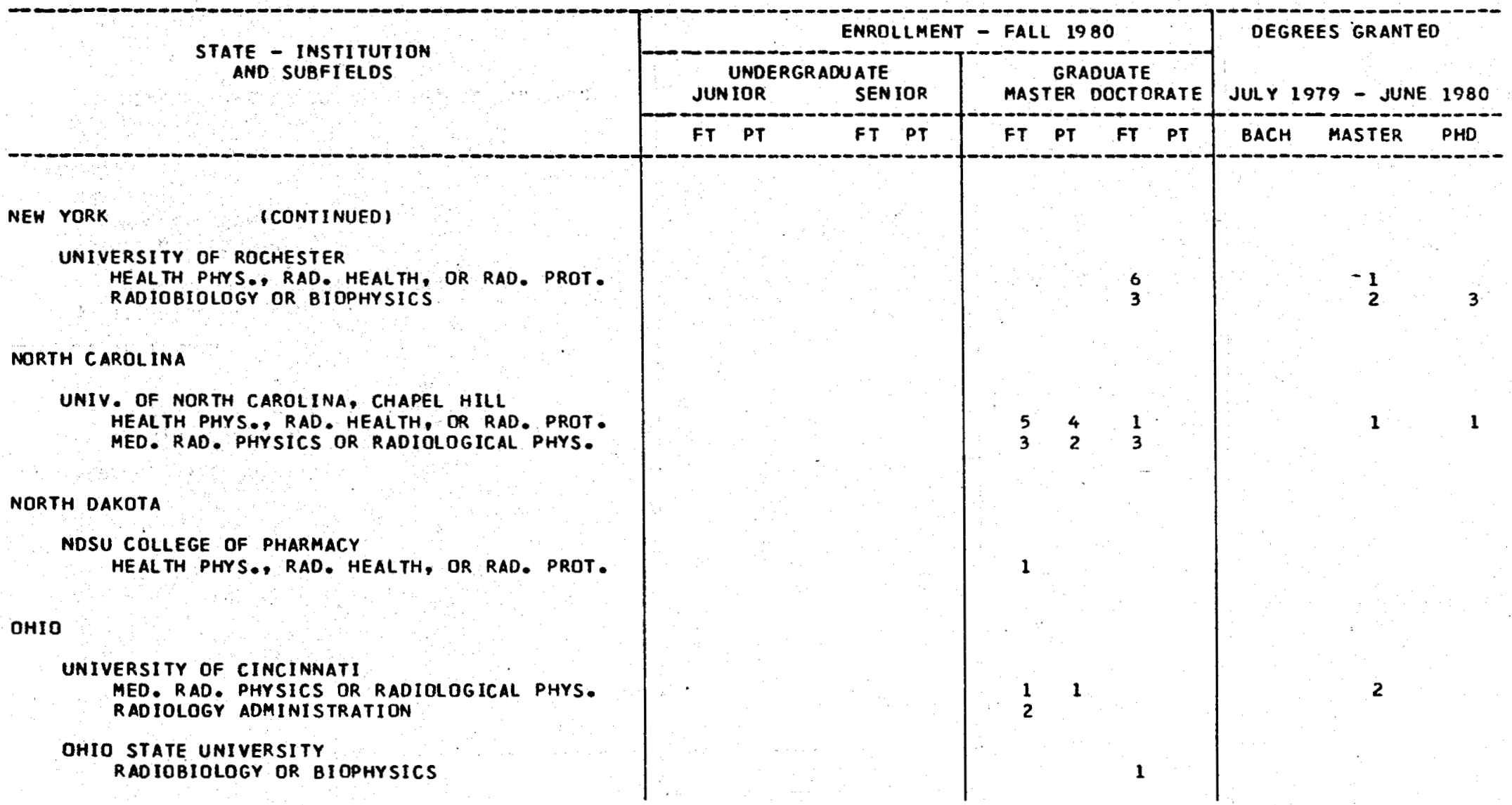


APPENDIX A-2 (Continued)

RADIATION PROTECTION

ENROLLMENTS AND DEGREES IN SUBFIELDS BY INSTITUTION

PT = PART TIME

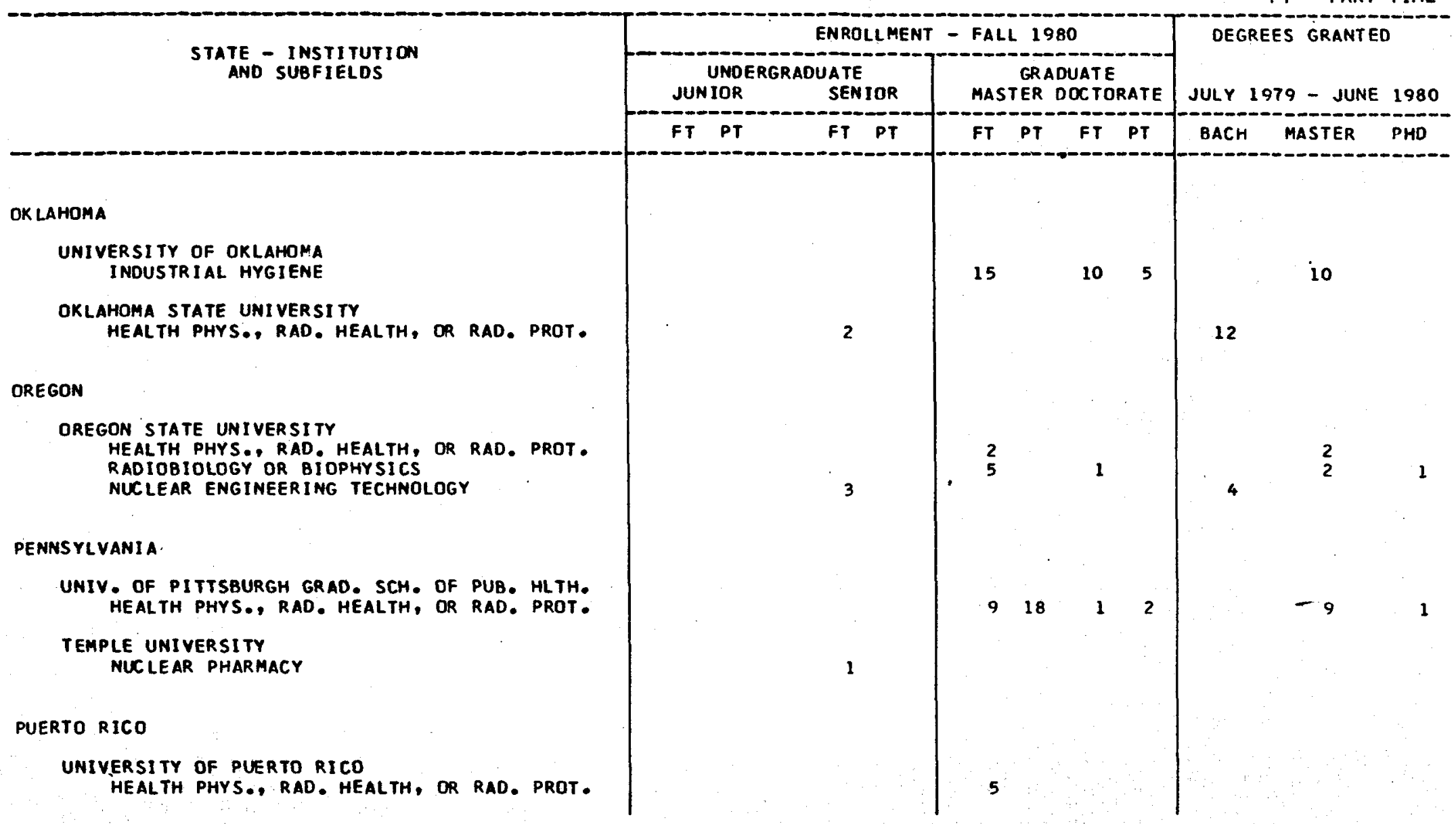


APPENDIX A-2 (Continued)

RADIATION PROTECTION

ENROLLMENTS AND DEGREES IN SUBFIELDS BY INSTITUTION

FT $=$ FULL TIME

PT = PART TIME

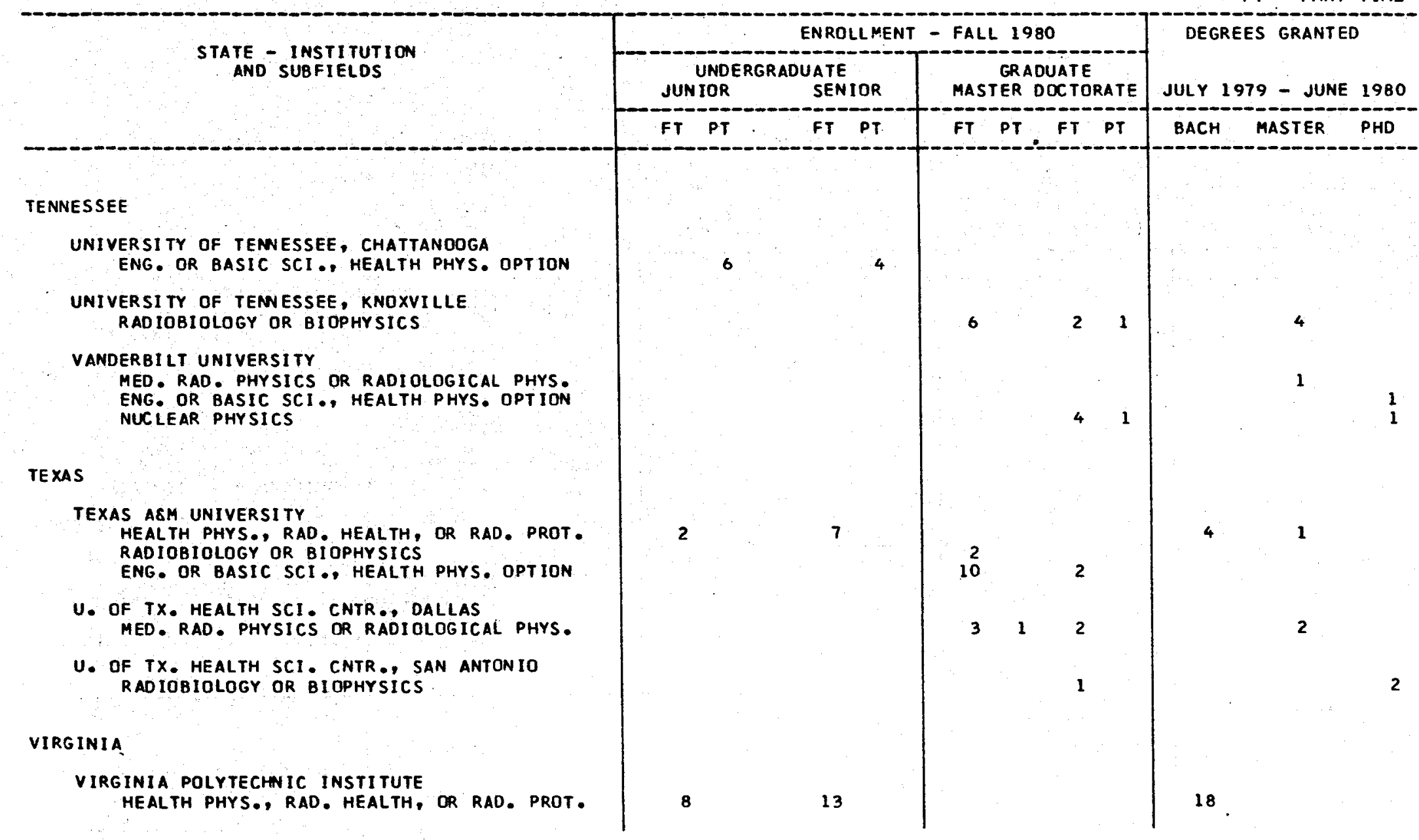


APPENDIX A-2 (Continued)

RADIATION PROTECTION

ENROLLMENTS AND DEGREES IN SUBF IELDS BY INSTITUTION

PT = PART TIME

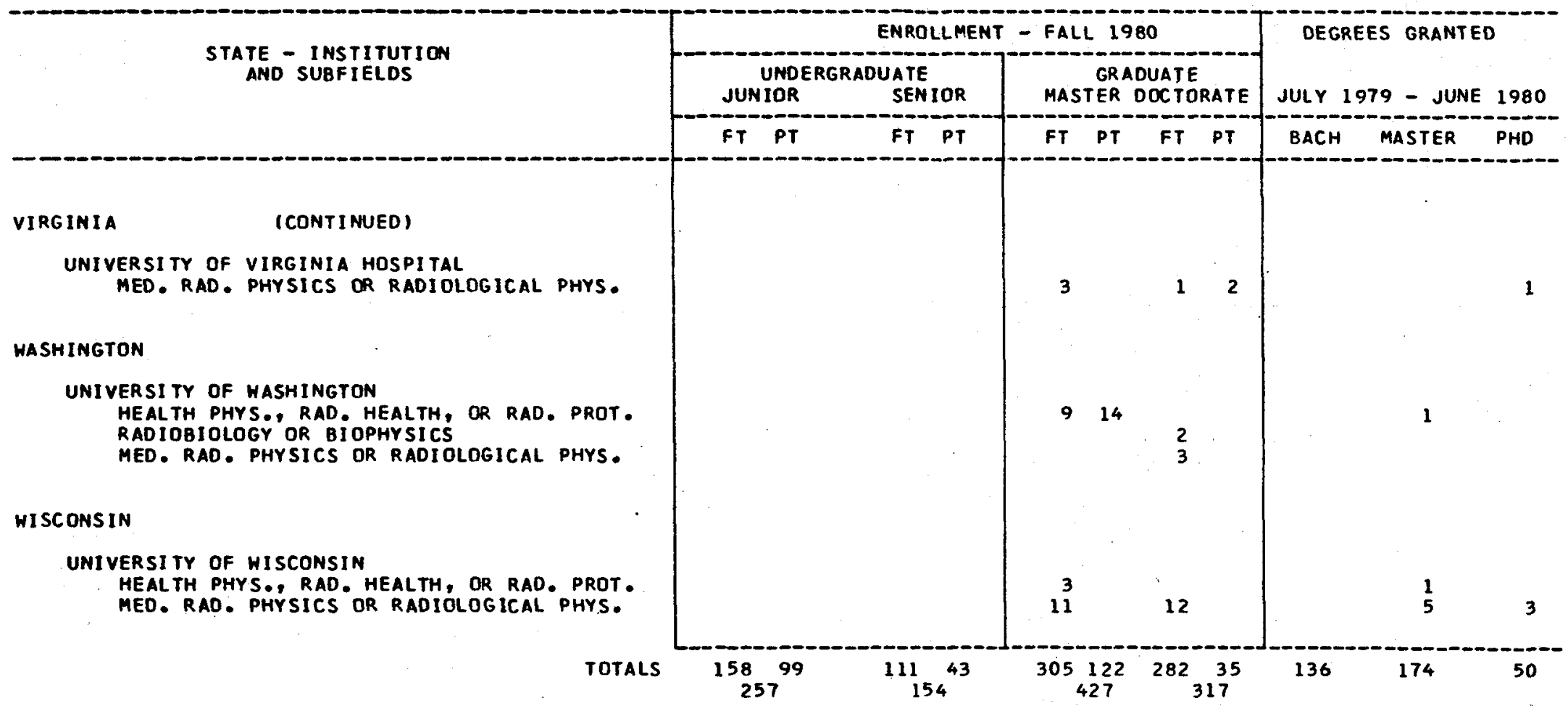




\section{APPENDIX A-3}

FOREIGN NATIONALS, WOMEN, AND MINORITIES: RADIAITON PROTECTION ENROLLMENTS AND DEGREES BY INSTITUTION

= FULL TIME

PT = PART TIME

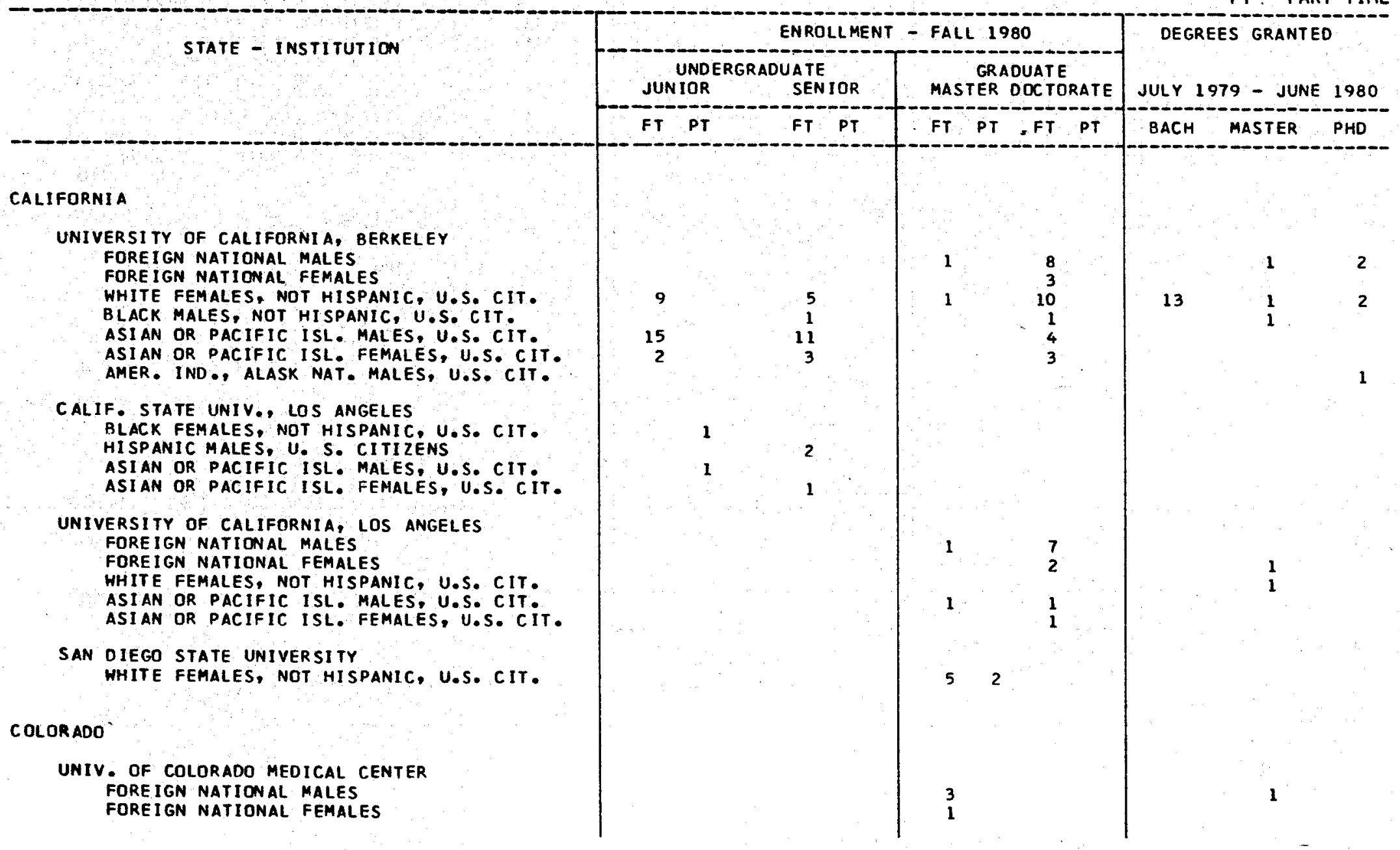


FOREIGN NATIONALS, WOMEN, AND MINORITIES: RADIATION PROTECTION ENROLLMENTS AND DEGREES BY INSTITUTION.

FLORIDA

UNIVERSITY OF FLORIDA

FORE IGN NATIONAL MALES

FORE IGN NATIONAL FEMALES

WHITE FEMALES, NOT HISPANIC, U.S. CIT

HI SPANIC MALES, U. S. CITIZENS

ASIAN OR PACIFIC ISL. MALES, U.S. CIT.

GEORGIA

EMORY UNIVERSI TY

FOREIGN NATIONAL MALES

WHITE FEMALES, NOT HISPANIC, U.S. CIT

BLACK MALES, NOT HISPANIC, U.S. CIT.

GEORGIA INSTITUTE OF TECHNOLOGY

FOREIGN NATIONAL MALES

WHITE FEMALES, NOT HISPANIC, U.S. CIT

BLACK FEMALES, NOT HISPANIC, U.S. CIT.

HISPANIC FEMALES, U. S. CITIZENS

FULL TIME

PT = PART TIME

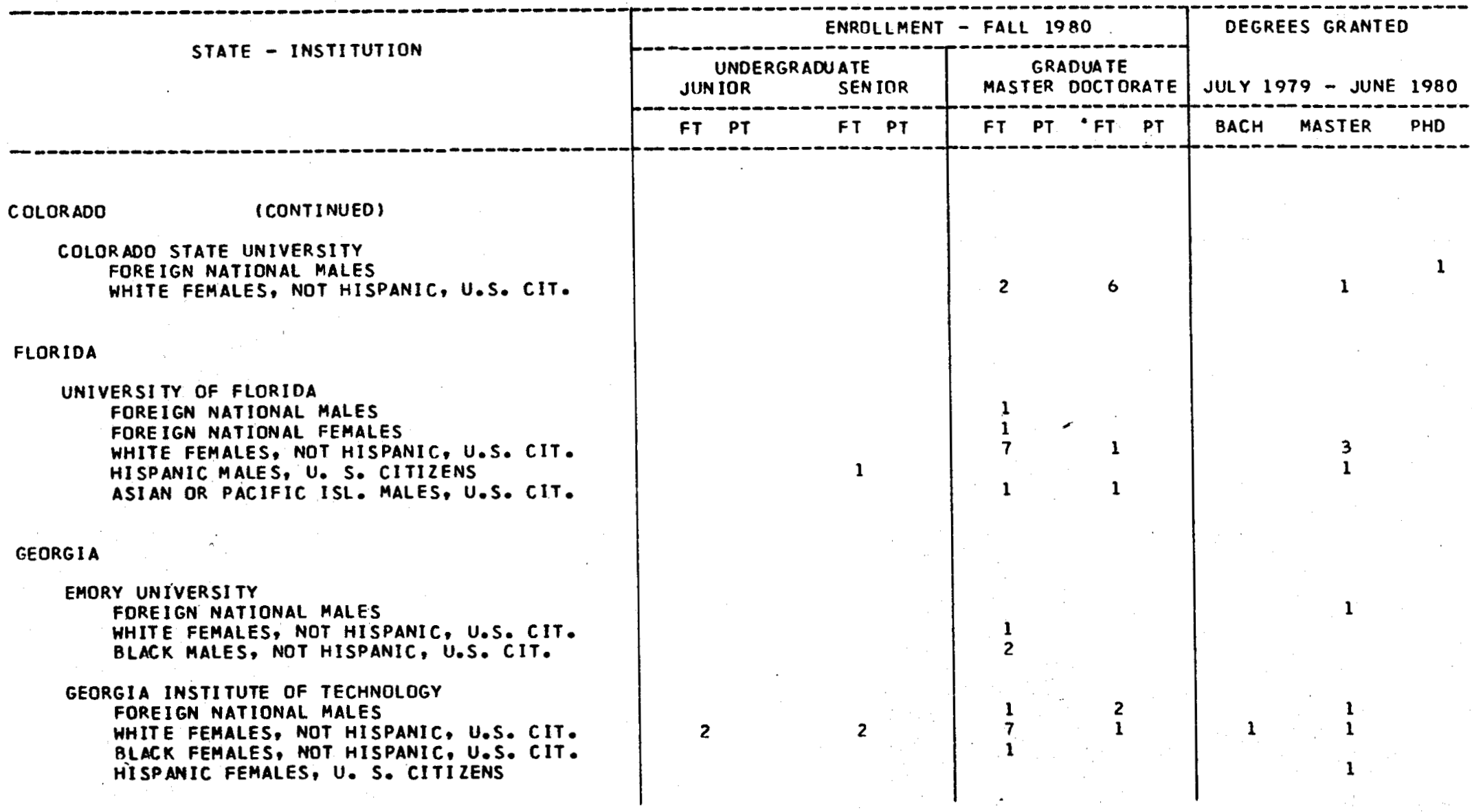


APPENDIX A-3 (Continued)

FOREIGN NATIONALS, WOMEN, AND MINORITIES: RADIATION PROTECTION ENROLLMENTS AND DEGREES BY INSTITUTION

= FULL TIME

PT = PART TIME

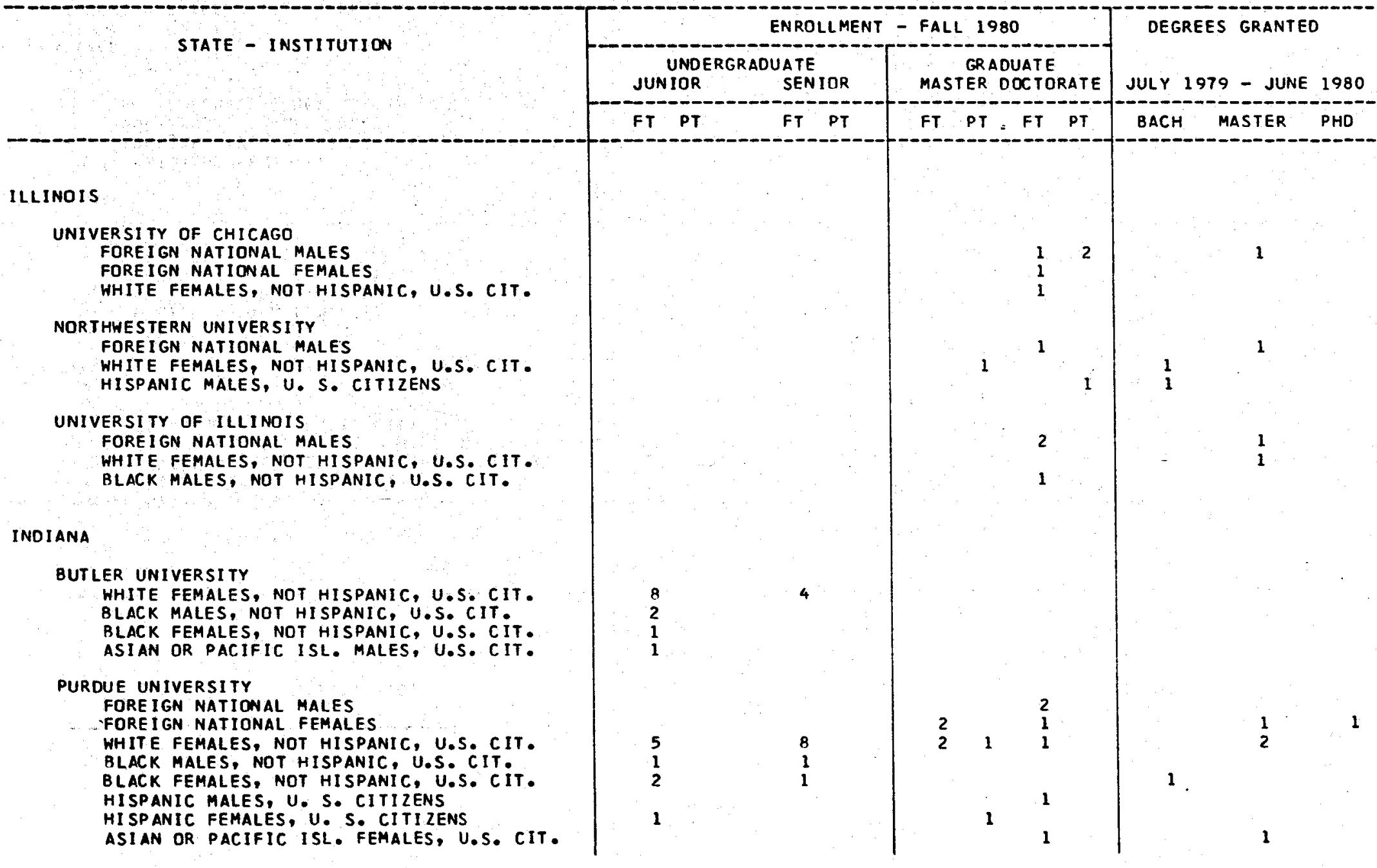


FOREIGN NATIONALS, WOMEN, AND MINORITIES: RADIATION PROTECTION ENROLLMENTS AND DEGREES BY INSTITUTION

$F T=$ FULL TIME

PT = PART TIME

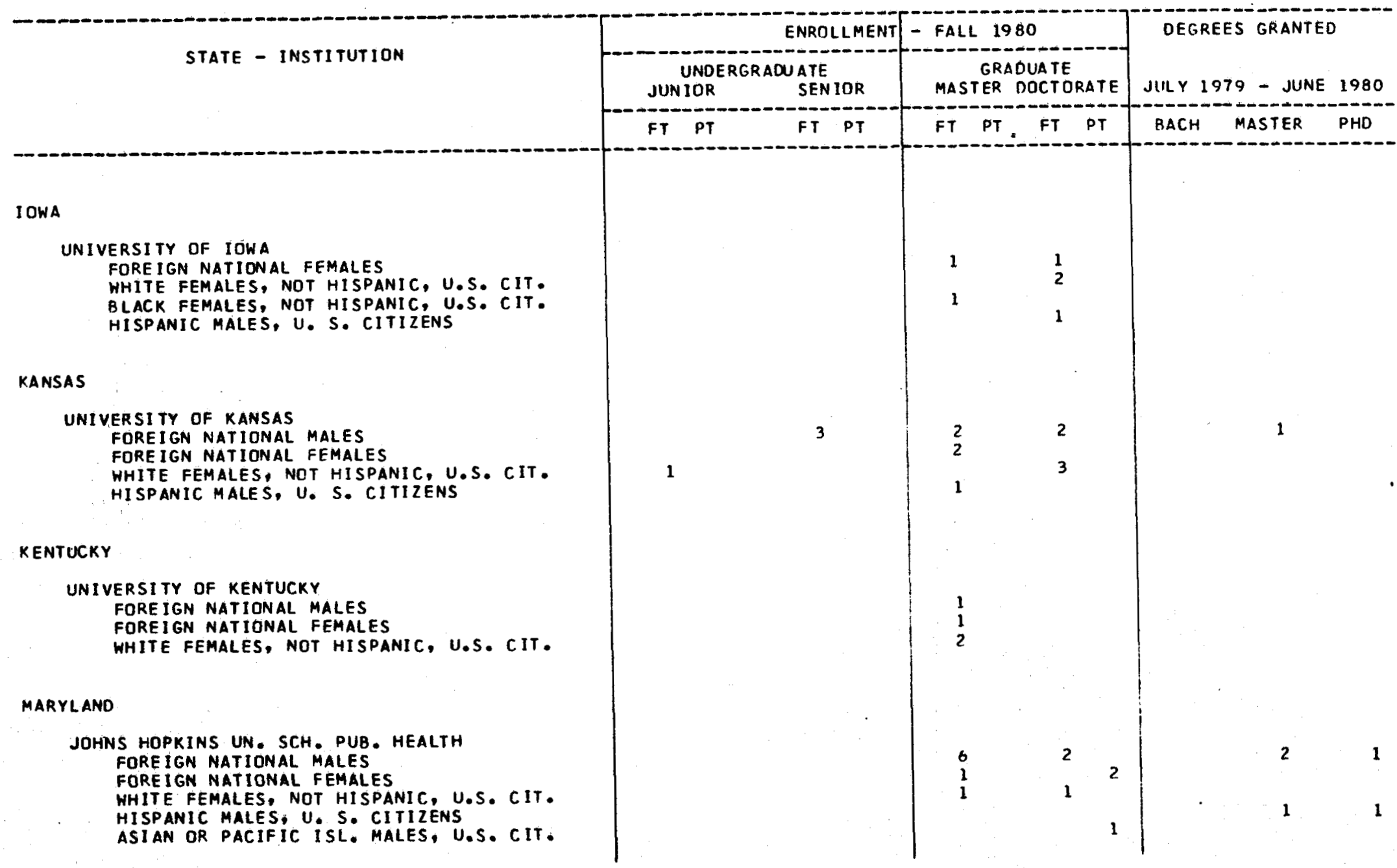


APPENDIX A-3 (Continued)

FOREIGN NATIONALS, WOMEN, AND MINORITIES: RADIATION PROTECTION ENROLLMENTS AND DEGREES BY INSTITUTION

PT $=$ PART TIME

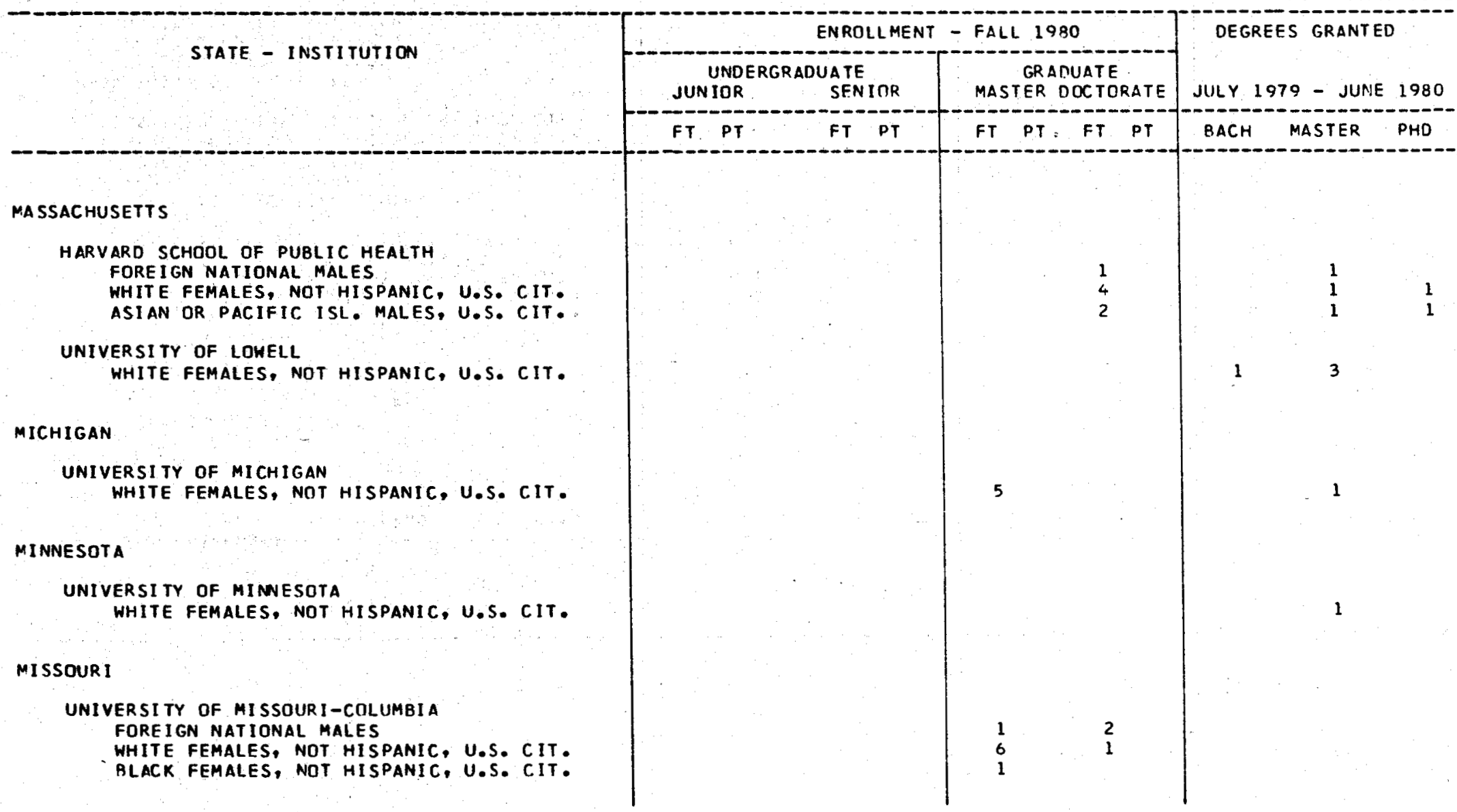


FOREIGN NATIONALS, WOMEN, AND MINORITIES: RADIATION PROTECTION

ENROLLMENTS AND DEGREES BY INSTITUTION

PT = PART TIME

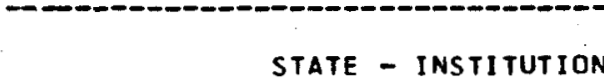

ENROLLMENT - FALL 1980

GRADUATE

UNDERGRADUATE

SENINR

MASTER DOCT RRATE

DEGREES GRANTED

NEW JERSEY

NEW JERSEY

RUTGERS UNIVERSITY

WHITE FEMALES, NOT HISPANIC, U.S. CIT .

NEW YORK

CLARKSON COLLEGE

FORE IGN NATIONAL FFMALES

MANHATTAN COLLEGE

FORE IGN NATIONAL FFMALES

WHITE FEMALES, NOT HISPANIC, U.S. CIT BLACK MALES, NOT HISPANIC, U.S. CIT. BLACK FEMALES, NOT HISPANIC, U.S. CIT.

HISPANIC FEMALES, U. S. CITIZENS

NEW YORK UNIV. MEDICAL CENTER

FOREIGN NATIONAL MALES

FORE IGN NATIONAL FEMALES

WHITE FEMALES, NOT HISPANIC, U.S. CIT ASIAN OR PACIFIC, ISL. MALES, U.S. CIT.

UNIVERSITY OF ROCHESTER

FORE IGN NATIONAL MALES

FOREIGN NATIOWAL FEMALES

WHITE FEMALES, NOT HISPANIC, U.S. CIT.
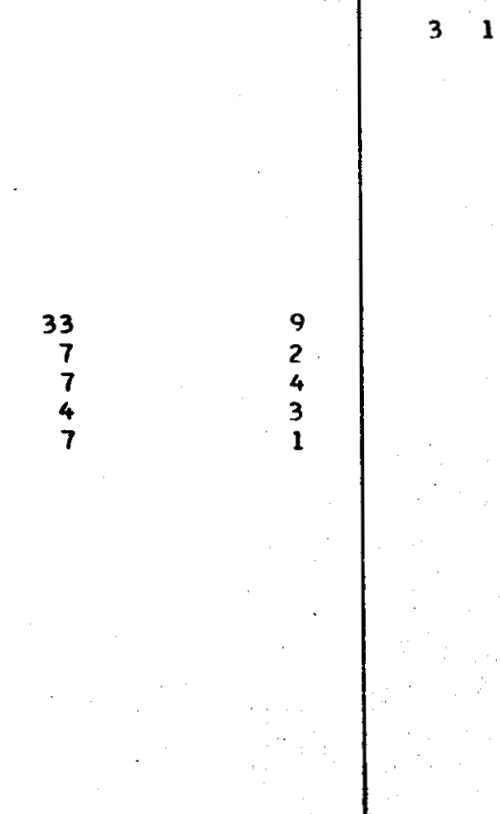

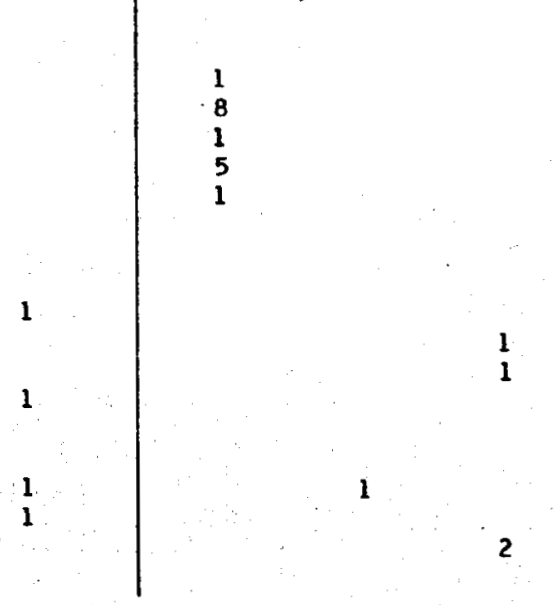


APPENDIX A-3 (Continued)

FOREIGN NATIONALS, WOMEN, AND MINORITIES: RADIATION PROTECTION

ENROLLMENTS AND DEGREES BY INSTITUTION

UNIVERSITY OF CINCINNATI

WHITE FEMALES, NOT HISPANIC, U.S. CIT.

OKLAHOMA

UNIVERSITY OF OKLAHOMA

FOREIGN NATIONAL MALES

HHITE FEMALES, NOT HISPANIC, U.S. CIT.

BLACK MALES, NOT HISPANIC, U.S. CIT.

BLACK FEMALES, NOT HISPANIC, U.S. CIT.

ASIAN OR PACIFIC ISL. MALES, U.S. CIT.

OKLAMOMA STATE UNIVERSITY

HHITE FEMALES, NOT HISPANIC, U.S. CIT.

OREGON

OREGON STATE UNIVERSITY

FORE IGN NATIONAL MALES

WHITE FEMALES, NOT HISPANIC, U.S. CIT.

ASIAN OR PACIFIC ISL. MALES, U.S. CIT.

$P T=$ PART TIME

DEREES GRANTED

\begin{tabular}{|c|c|c|c|c|}
\hline & \multicolumn{3}{|c|}{ ENROLLMENT - FALL 1980} & \multirow{2}{*}{$\begin{array}{l}\text { DEGREES GRANTED } \\
\text { JULY } 1970^{\circ}-\text { JUNE } 1980\end{array}$} \\
\hline & & $\begin{array}{l}\text { UATE } \\
\text { SEN IOR }\end{array}$ & $\begin{array}{c}\text { GRADUATE } \\
\text { MASTER DOCTORATE }\end{array}$ & \\
\hline FT & PT & FT & $F T=P T=F T \quad P T$ & MASTER \\
\hline
\end{tabular}

UNIV. OF NORTH CAROLINA, CHAPEL HILL

WHITE FEMALES, NOT HISPANIC, U.S. CIT. 
FOREIGN NATIONALS, WOMEN, AND MINORITIES: RADIATION PROTECTION ENROLLMENTS AND DEGREES BY INSTITUTION

$F T$ = FULL TIME

PT = PART TIME

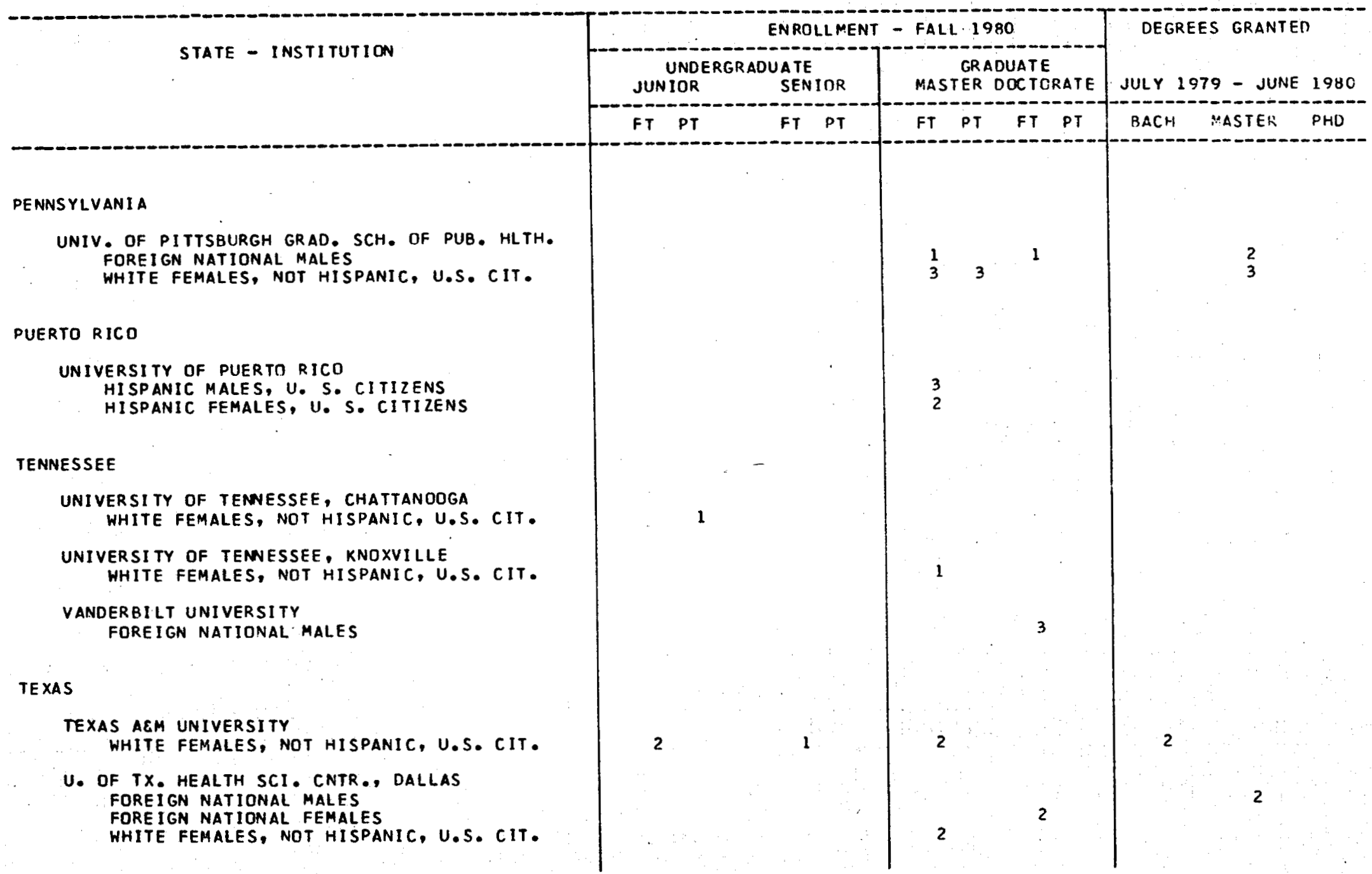




\section{APPENDIX A-3 (Continued)}

FOREIGN NATIONALS, WOMEN, AND MINORITIES: RADIATION PROTECTION ENROLLMENTS AND DEGREES BY INSTITUTION

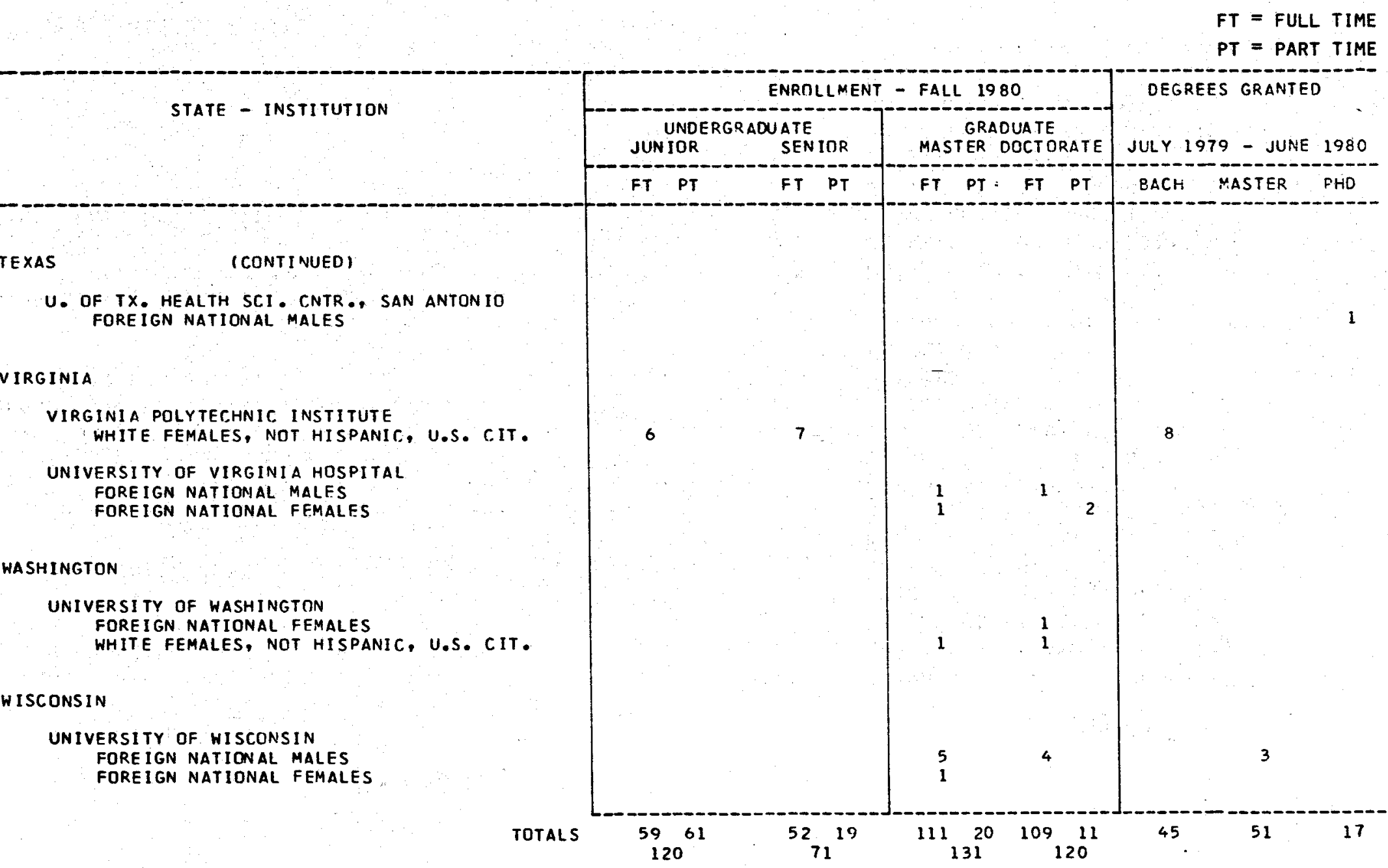


APPENDIX A-4

- radiation PROTECTION CURRICULA

OR OPTIONS BY UNDERGRADUATE OR GRADUATE INSTITUTION,

FALL 1980

HEALTH PHYSICS, RADIATION HEALTH, OR RADIATION PROTECTION

\section{UNDERGRADUATE}

Arizona State University.................. Arizona State University

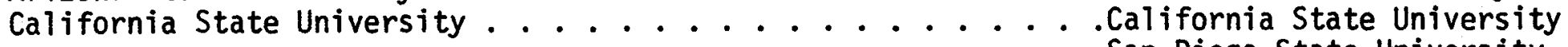

San Diego State University

Colorado State University

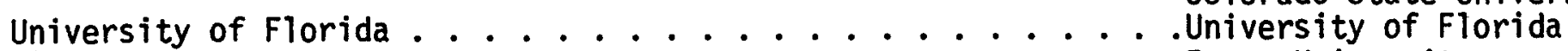

Emory University

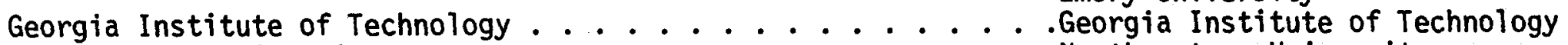

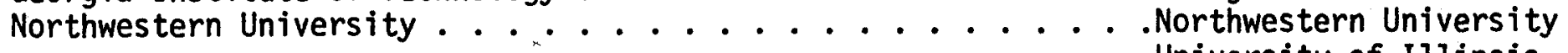

University of Illinois

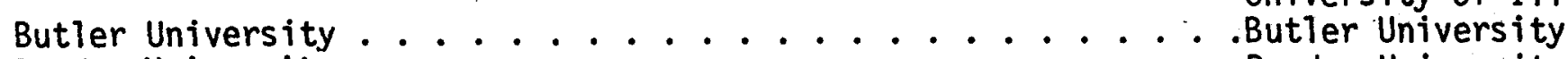

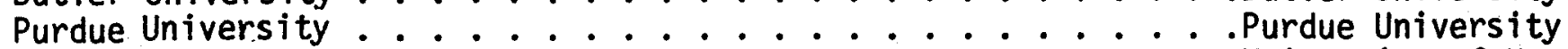

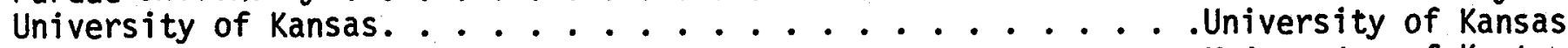

University of Kentucky

Harvard School of Public Health

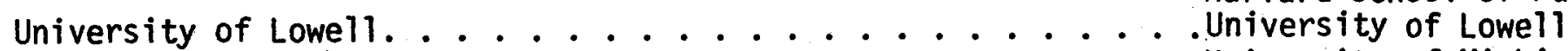

University of Michigan

University of Minnesota

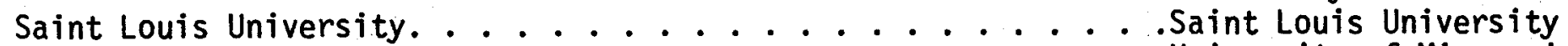

University of Missouri, Columbia

Rutgers University

New York University, Medical Center.

University of Rochester

University of North Carolina, Chapel Hill

OkTahoma State University

North Dakota State University

Duquesne University

Oregon State University

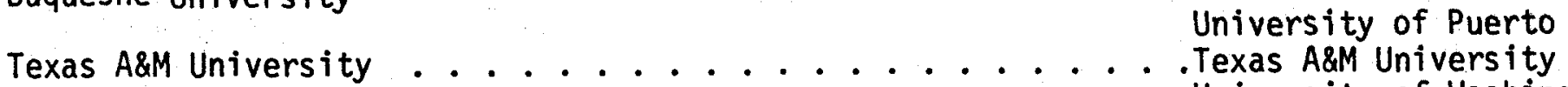

University of Washington

University of Wisconsin 
APPENDIX A-4 (Continued)

RADIATION PROTECTION CURRICULA

OR OPTIONS BY UNDERGRADUATE OR GRADUATE INSTITUTION,

FALL 1980

RADIOBIOLOGY OR BIOPHYSICS

\section{UNDERGRADUATE}

\section{GRADUATE}

University of California, Berkeley.......... University of California, Berkeley Colorado State University

University of Illinois

Butler University ............................. Uutler University

University of Iowa

Harvard School of Public Health

University of Rochester

Ohio State University

University of Tennessee

Texas A\&M University

University of Texas Health Science Center, Dallas

University of Washington

MEDICAL RADIATION PHYSICS OR RADIOLOGICAL PHYSICS

California State University, Los Angeles

Unviversity of California, Los Angeles

University of Colorado Medical Center

University of Florida

University of Chicago

University of Illinois

Butler University

Purdue University

University of Kansas

University of Kentucky

Johns Hopkins University School of

Public Health

Harvard School of Public Health

University of Missouri, Columbia

Rutgers University

Manhattan College

Cornell University, Sloan-Kettering Division 
OR OPTIONS BY UNDERGRADUATE OR GRADUATE INSTITUTION,

FALL 1980

MEDICAL RADIATION PHYSICS OR RADIOLOGICAL PHYSICS (Continued)

UNDERGRADUATE

GRADUATE

University of North Carolina, Chapel Hill

University of Cincinnati

Vanderbilt University

University of Texas Heal th Science

Center, Dallas

University of Virginia Hospital

University of Washington

University of Wisconsin

ENGINEERING OR BASIC SCIENCES, HEALTH PHYSICS OPTION

Rensselaer Polytechnic Institute. . . . . . . . . . Rensselaer Polytechnic Institute

Rutgers University

University of Tennessee, Chattanooga

Vanderbilt University

Texas A\&M University

BIOENGINEERING

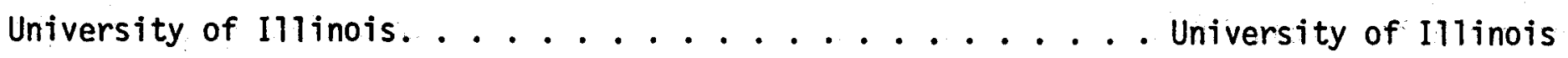

ENVIRONMENTAL HEALTH

Purdue University . . . . . . . . . . . . . Purdue University

INDUSTRIAL HYGIENE

University of Oklahoma, Health Sciences Center

NUCLEAR PHARMACY

Temple University

Purdue University 
APPENDIX A-4 (Continued)

RADIATION PROTECTION CURRICULA

OR OPTIONS BY UNDERGRADUATE OR GRADUATE INSTITUTION,

FALL 1980

NUCLEAR PHYSICS

UNDERGRADUATE

GRADUATE

Vanderbilt University

RADIATION CHEMISTRY

Rutgers University

RADIATION INSTRUMENTATION

Butler University

RADIATION PHYSICS

Clarkson College

RADIOECOLOGY

Colorado State University

RADIOLOGY ADMINISTRATION

University of Cincinnati

VETERINARY RADIOLOGY

Colorado State University 
APPEND IX A-5

RADIATION PROTECTION

ENROLLMENTS AND DEGREES IN SUBFIELDS BY STATE AND REGION

$F T=F U L L$ TIME

PT = PART TIME

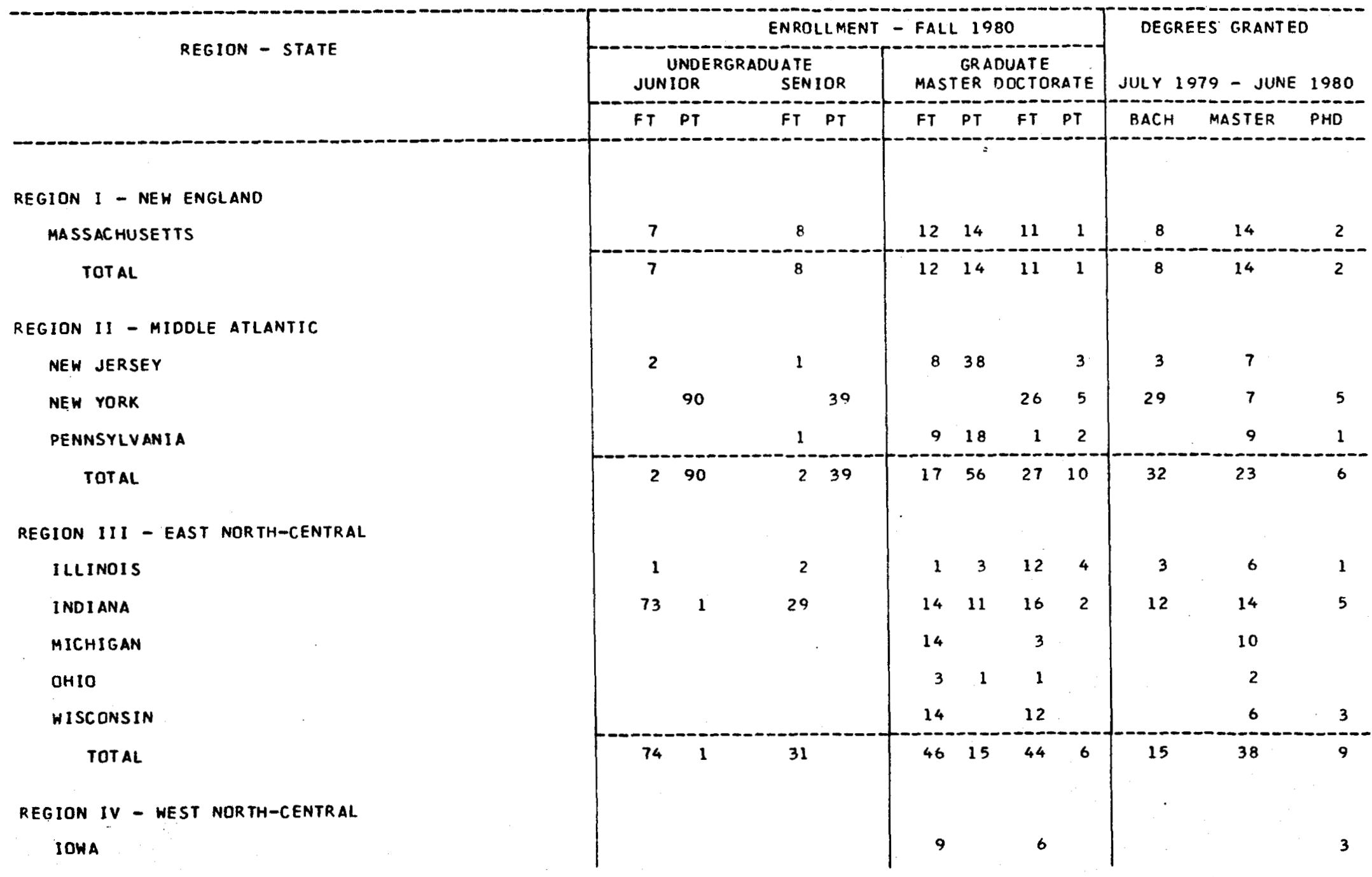


APPENDIX A- 5 (Continued)

RADIATION PROTECTION

ENROLLMENTS AND DEGREES IN SUBFIELDS BY STATE AND REGION

T = FULL TIME

PT = PART TIME

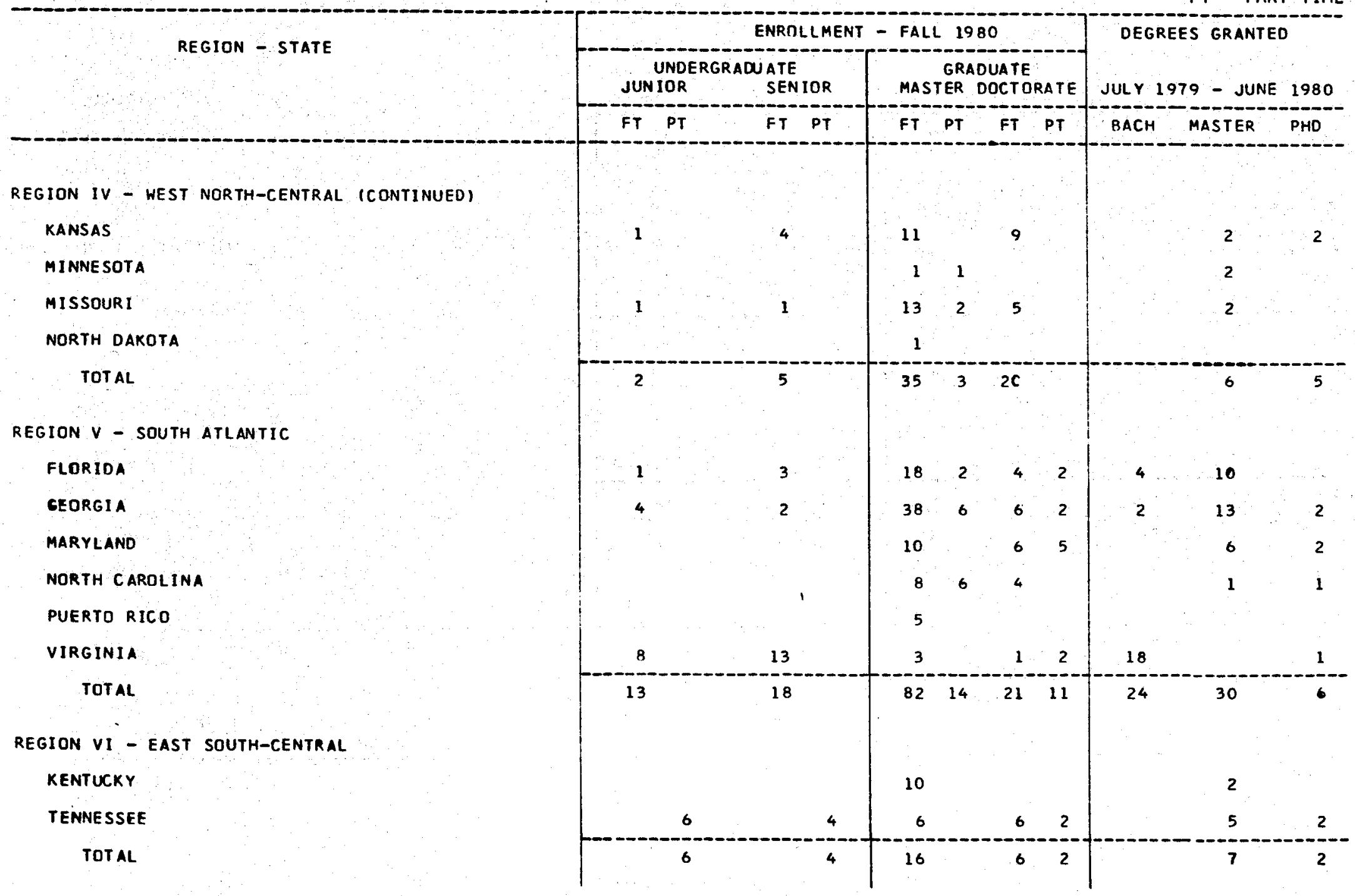




\section{APPENDIX A- 5 (Continued)}

RADIATION PROTECTION

ENROLLMENTS AND DEGREES IN SUBFIELDS BY STATE AND REGION

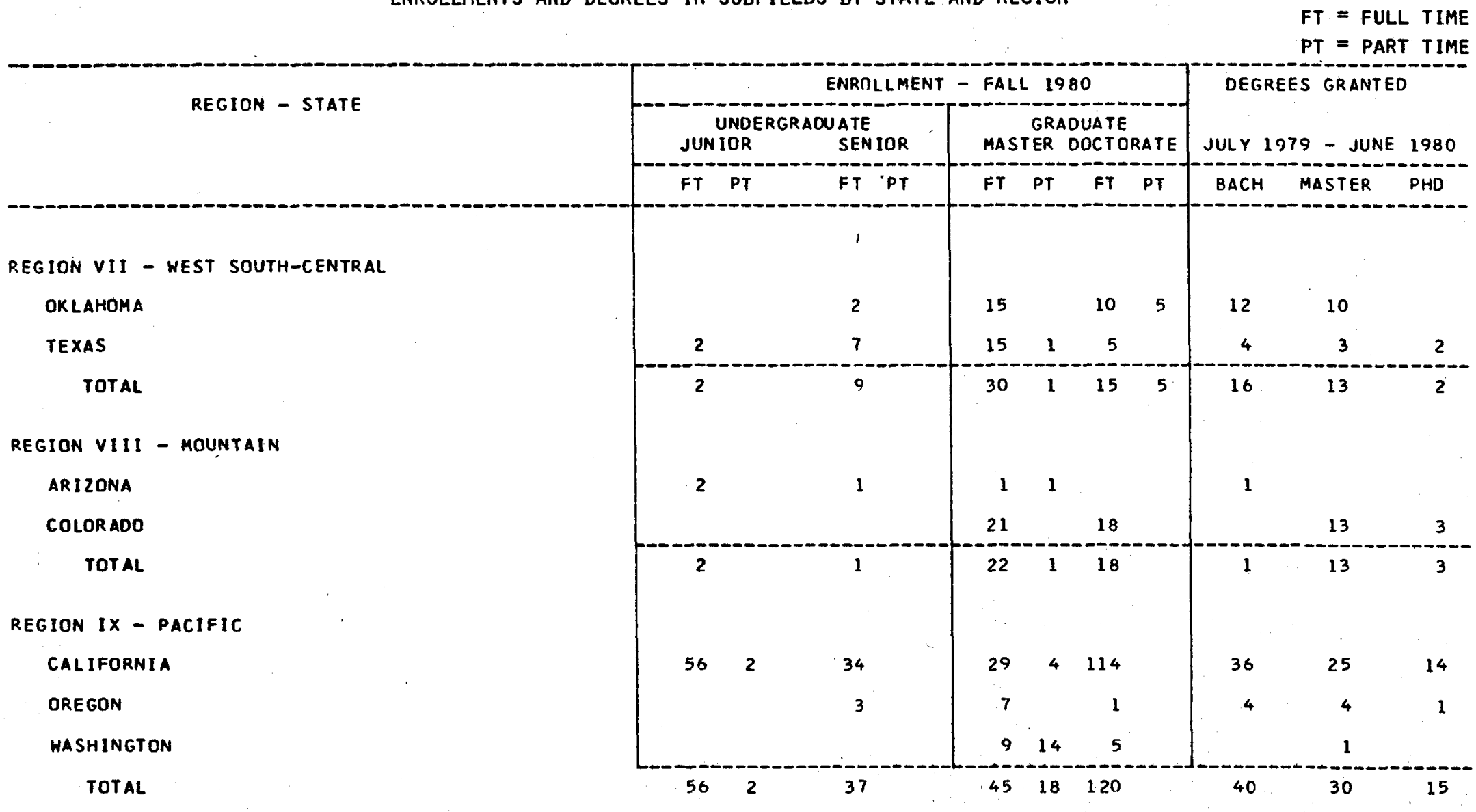


APPENDIX B-1

ADDRESSES OF INSTITUTIONS IN SURVEY UNIVERSE WITH ACTIVE PROGRAMS

in RADIATION PROTECTION, 1980

Arizona State University

Department of Engineering

Tempe, Arizona 85281

California State University, Los Angeles

Department of Physics

Los Angeles, California 90032

San Diego State University

Department of Physics

San Diego, California 92182

University of California, Berkeley

Group in Biophysics and Medical Physics

\&

University of California, Los Angeles

Department of Radiological Sciences

Los Angeles, California 90024

Colorado State University

Department of Radiology and

Radiation Biology

Fort Collins, Colorado 80523

University of Colorado Medical Center

Department of Radiology

Denver, Colorado 80262

University of Florida

Department of Nuclear Engineering Sciences and Department of Enviromental Engineering

Gainesville, Florida 32611

Emory University

Department of Radiological Scie ices

Decatur, Georgia 30322

Georgia Institute of Technology School of Nuclear Engineering Atlanta, Georgia 30332

Northwestern University Department of Civil Engineering Evanston, Illinois 60201

University of Chicago

Department of Radiology

Chicago, Illinois 60637

University of Illinois, Urbana

Nuclear Engineering Program

Urbana, Illinois 61801

Butler University

Department of Bionucleonics

Indianapolis, Indiana 46208

Purdue University

Department of Bionucleonics

West Lafayette, Indiana 47907

University of Iowa

Radiation Research Laboratory

Iowa City, Iowa 52242

University of Kansas

Department of Radiation Biophysics

Lawrence, Kansas 66045

University of Kentucky

Department of Health Radiation Sciences

Lexington, Kentucky 40506 
ADDRESSES OF INSTITUTIONS IN SURVEY UNIVERSE WITH ACTIVE PROGRAMS

in RADIATION PROTECTION,

The Johns Hopkins University 1980

School of Hygiene \& Public Health

Department of Environmental Health Sciences

Baltimore, Maryland 21205

Harvard University School of Public Health Department of Environmental Health Sciences

Boston, Massachusetts 02115

University of Lowell

Department of Radiological Sciences/Protection

Lowe11, Massachusetts 01854

University of Michigan

fo Department of Environmental

and Industrial Health

Ann Arbor, Michigan 48109

University of Minnesota

Department of Environmental Health

Minneapolis, Minnesota 55455

St. Louis University

Department of Physics

St. Louis, Missouri 63103

University of Missouri, Columbia

Graduate Studies in Nuclear Engineering

Columbia, Missouri 65211

Rutgers University

Department of Radiation Sciences

New Brunswick, New Jersey 08903

Clarkson College of Technology

Department of Physics

Potsdam, New York 13676
Cornell University Graduate School of Medical Sciences

Memorial Sloan-Kettering Cancer Center 1275 York Avenue

New York, New York 10021

Manhattan College

Department of Radiological and Health Sciences

Riverdale, New York 10471

New York University Medical Center Department of Environmental Medicine New York New York 10016

Rensselaer Polytechnic Institute Department of Chemical \& Environmental Engineering

Troy, New York 12181

University of Rochester

School of Medicine \& Dentistry

Department of Radiation Biology and Biophysics

Rochester, New York 14642

University of North Carolina, Chapel Hill

Department of Environmental Sciences and Engineering

Chapel Hill, North Carolina 27514

North Dakota State University

School of Pharmacy

Department of Pharmaceutical Chemistry and Bionucleonics

Fargo, North Dakota 58105 
APPENDIX B-1 (Continued)

ADDRESSES OF INSTITUTIONS IN SURVEY UNIVERSE WITH ACTIVE PROGRAMS

in RADIATION PROTECTION,

Ohio State University

Department of Biophysics

Columbus, Ohio 43210

University of Cincinnati

Department of Radiology

Cincinnati, Ohio 45267

Oklahoma State University

Department of Radiation and

Nuclear Technology

Stillwater, Oklahoma 74074

Unviersity of Oklahoma

Health Sciences Center

Department of Environmental Health

Norman, Oklahoma 73190

Oregon State University

Department of General Science

Corvallis, Oregon 97331

Temple University School of Pharmacy

Department of Pharmaceutical Chemistry

Philadelphia, Pennsylvania 19140

University of Pittsburgh, Graduate School of Public Health

Department of Radiation Heal th

Pittsburgh, Pennsylvania 15261

University of Puerto Rico

Environmental Health Department

San Juan, Puerto Rico 00936

University of Tennessee, Chattano ga

Department of Physcis

Chattanooga, Tennessee 37401

\section{0}

University of Tennessee, Knoxville Department of Physics

Knoxville, Tennessee 37916

Vanderbilt University

Department of Physics-Astronomy

Nashville, Tennessee $\mathbf{3 7 2 3 5}$

Texas A\&M University

Department of Radiological Safety

College Station, Texas 77843

University of Texas Health Science Center, Dallas

Department of Radiology

Dallas, Texas 75235

University of Texas Health Science Center Medical Physics-Radiology Center

San Antonio, Texas 78227

University of Virginia Hospital

Radiology Department

Charlottesville, Virginia 22908

Virginia Polytechnic Institute and State University

Department of Biology

Blacksburg, Virginia 24601

University of Washington

Department of Radiological Sciences

Seattle, Washington 98195

University of Wisconsin, Madison

Department of Radiology-Medical Physics

Madison, Wisconsin 53706 
APPENDIX B-2

ADDRESSES OF INSTITUTIONS IN SURVEY UNIVERSE

WITH INACTIVE, AND DISCONTINUED PROGRAMS

in RADIATION PROTECTION,

\section{INACTIVE}

University of Alabama, Birmingham Department of Physics

Birmingham, Alabama 35294

Butler University

Bionucleonics

Indianapol is, Indiana 46208

University of Puerto Rico

Environmental Health Department

$\vec{\infty}$

San Juan, Puerto Rico 00936

Middle Tennessee State University Department of Chemistry \& Physics

Murfreesboro, Tennessee 37132

University of Alabama, Birmingham Department of Physcis

Birmingham, Alabama 35294

Middle Tennessee State University Department of Chemistry \& Physics

Murfreesboro, Tennessee 37132

Duquesne University

Department of Radiological Health

Pittsburgh, Pennsylvania 15219
1979

\section{DISCONTINUED}

Temple University

Pharmaceutical Chemistry

Philadelphia, Pennsylvania 19140

(Started again in 1980) 


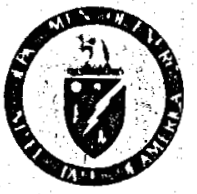

Department of Energy

Washíngton, D.C. 20585

September 22, 1980

\section{Dear Professor:}

The enclosed forms are designed to obtain data concerning the potential supply of radiation protection personne1. This survey is carried out by the Department of Energy (DOE) in partial fulfiliment of $i$ ts requirement to "assure an adequate supply of manpower for the accomplishment of energy research and development programs,.... by...the collection, analys is and dissemination of necessary manpower supply and demand data...," which is mandated in P.L. 93-438, the Energy Reorganization Act of 1974, as amended.

The survey is sent to all colleges with programs in any curriculum the successful completion of which would prepare the graduate to take a major role in conducting, coordinating, directing, or planning a program for the evaluation and control of radiation hazards for an installation, cormunity or government agency.

You are not required to respond to this survey, but we hope that you will cooperate. We wish to make the results as comprehensive, accurate and timely as possible. The information obtained is published and widely distributed. It is used by al1 levels of government and industry for recruitment purposes, and by students and educational institutions for identifying the availability of special curriculums. None of the information is used in any way that could be construed as anything but beneficial to the institutions which participate. Because the form does not request any individually identifiable data on students, DOE does not consider the information confidential.

Complete instructions and definitions needed in filling out the form are included on the form itself. Please complete it and return it to the following address at your earl iest convenience:

Ruth M. Gove

Oak Ridge Associated Universities

P.0. Box 117

Oak Ridge, Tennessee $37830 \quad$ (615) $576-3314$

A stamped, self-addressed envelope is enclosed for your convenience. Thank you for your cooperation.

Sincerely,

Nornen Seitia

Norman Seltzer

Chief, Manpower Assessment 
APPENDIX C (Continued) SURVEY MATERIALS

DOE Form IR-617

IMPORTANT: Before completing this form, plosse see instructions and definitions on

U. S. Department of Energy

FORM APPAOVED the bock.

RADIATION PROTECTION ENROLLMENT AND DEGREE SURVEY: 1980

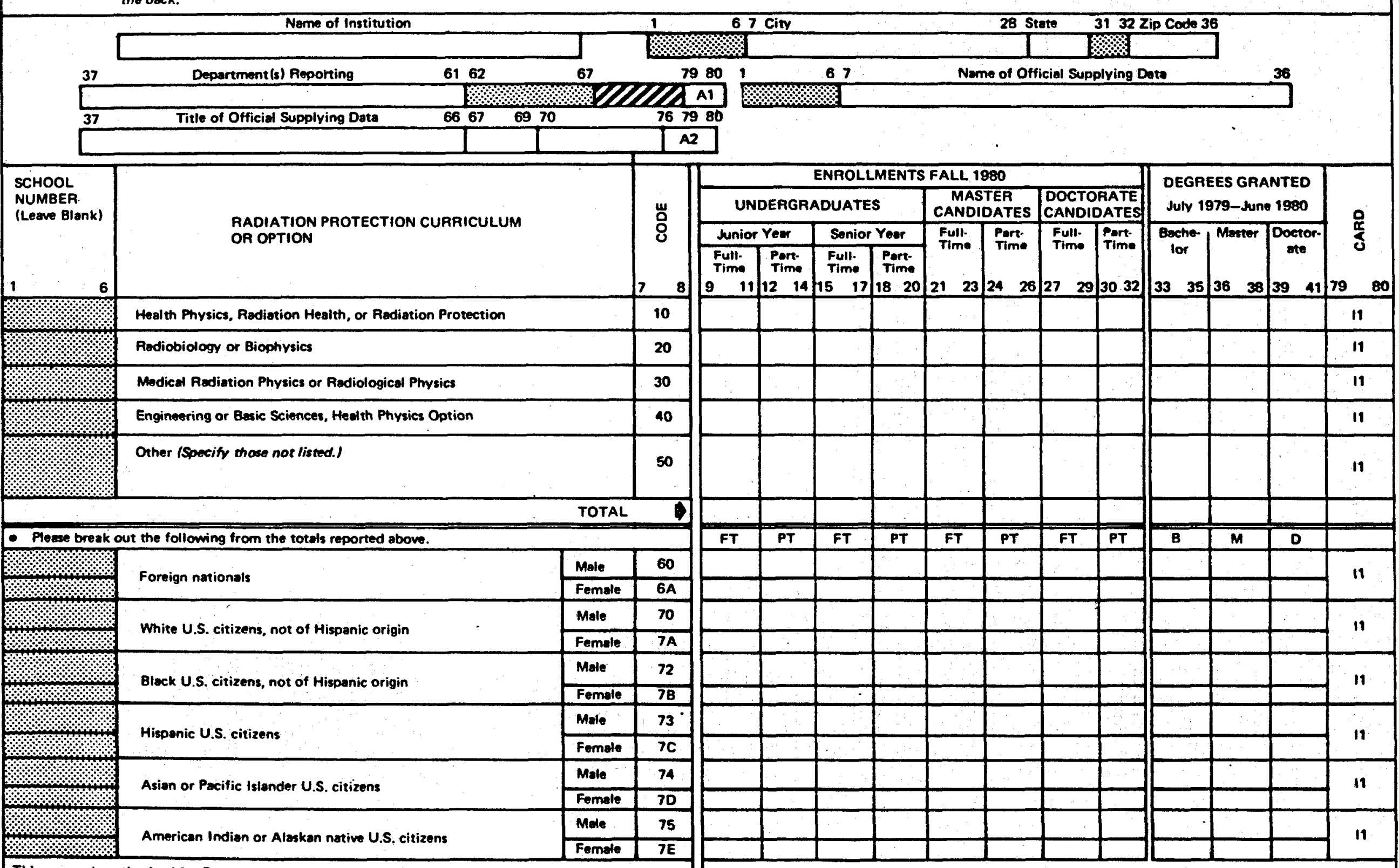

This survey is authorized by Public Law 93-438, a amended. While you are not requined to respond your cooperation is needed to make the results comprehensive, accurate, and timely. Information will

Remarks: 


\title{
APPENDIX C (Continued)
}

\section{SURVEY MATERIALS}

Note: Information provided through this survey will not be held confidential.

\author{
INSTRUCTIONS AND DEFINITIONS FOR COMPLETING DOE FORM IR-617
}

PURPOSE: This voluntary survey is conducted for the Department of Energy (DOE) in partial fulfillment of its obligation "to assure an adequate supply of manpower for the accomplishment of energy research and development programs... by...the collection, analysis, and dissemination of necessary manpower supply and demand data," as mandated in the Energy Reorganization Act of 1974 (P.L. 93-438), as amended. It is used to determine, by degree level, the yeariy supply and antici-pated supply of those trained in health physics, radiation health or safety, radiological health, or similar programs, who would be qualified to be responsible for some major phase of a program for the evaluation and control of radiation hazards.

WHO SHOULD COMPLETE AND SUBMIT FORMS: All departments with programs in any curriculum the successful completion of which will equip graduates to take the major role in conducting, coordinating, directing, or planning a program for the evaluation and control of radiation hazards for an installation, community, or State agency. Each major program should be reported on the appropriate ifine or on separate lines in the write-in space. Very small specialties should be combined.

WHEN AND WHERE TO SUBMIT FORMS: Forms should be submitted within two weeks of receipt, or at the latest, by mid-November, depending upon your institution's enrollment schedule. Send completed forms to:

Ruth M. Gove

Oak Ridge Associated Universities

P.0. Box 117

Oak Ridge, Tennessee (615) 576-3314

A self-addressed, postage-paid envelope is enclosed for your convenience.

SPECIAL INSTRUCTIONS: Report only students enrolled in a degree program. Count co-op students (see definition below) as full-time students. If exact figures are not avallable, give your best estimate and indicate by an "E" after each number that is estimated.

DEFINITIONS:

Junior: A student who is more than one and less than two academic years short of a Bachelor's degree or equivalent.

Senior: A student who is one year or less short of a Bachelor's degree or equivalent.

Master's Candidate: A student enrolled in a program leading to any degree below the Ph.D. and above the BS or BA (i.e., a fifth year student in an integrated program leading directly to the MS or a candidate for a first professional degree).

CO-OP Student: A student who alternates sessions of schooling with sessions of employment in a position related to the academic specialty.

Foreign National: Any student who is a citizen of another country and who has not applied for U.S. citizenship.

White not of Hispanic origin: A person having origin in any of the original peoples of Europe, North Africa, or the Middle East.

Black not of Hispantc origin: A person having origin in any of the black racial groups of Africa.

Hispanic: A person of Mexican, Puerto Rican, Cuban, Central or South American, or other Spanish culture or origin regardless of race.

Asian or Pacific Islander: A person having origin in any of the original peoples of the Far East, Southeast Asia, the Indian subcontinent, or the Pacific Islands.

American Indian or Alaskan Native: A person having origin in any of the original peoples of North America and who maintains cultural identification through tribal affiliation or comunity recognition. 


\section{APPENDIX C (Continued)}

SURVEY MATERIALS

DOE Form IR-617.A

U. S. Depertment of Energy

FORM PROVED

RADIATION PROTECTION ENROLLMENT AND DEGREE SURVEY-SUPPLEMENT

Reporting Institution

Date

Please indicate plecement or plans of desree recipients for July 1979-June 1980

\begin{tabular}{|c|c|c|c|c|c|c|}
\hline \multirow[b]{2}{*}{$\begin{array}{l}\text { PLACEMENT OA PLANS } \\
\text { AFTER GRADUATION }\end{array}$} & \multicolumn{2}{|c|}{ BACHELORS } & \multicolumn{2}{|c|}{ MASTERS } & \multicolumn{2}{|c|}{ DOCTORATES } \\
\hline & $\begin{array}{c}\text { Total } \\
\text { Groduates }\end{array}$ & $\begin{array}{l}\text { Foreign } \\
\text { Netiondls }\end{array}$ & $\begin{array}{l}\text { Total } \\
\text { Greduates }\end{array}$ & $\begin{array}{l}\text { Foreign } \\
\text { Nationals }\end{array}$ & $\begin{array}{c}\text { Total } \\
\text { Graduates }\end{array}$ & $\begin{array}{l}\text { Foreigh } \\
\text { Nationais }\end{array}$ \\
\hline \multicolumn{7}{|l|}{ Further study } \\
\hline \multicolumn{7}{|l|}{$\begin{array}{l}\text { U.S. acsodemic employment } \\
\text { (show students employed } \\
\text { part time under further } \\
\text { study) }\end{array}$} \\
\hline \multicolumn{7}{|l|}{$\begin{array}{l}\text { Federel government } \\
\text { employment }\end{array}$} \\
\hline \multicolumn{7}{|l|}{$\begin{array}{l}\text { Government-owned, contrec- } \\
\text { tor-opereted instilletions } \\
\text { employment (GOCO's) }\end{array}$} \\
\hline \multicolumn{7}{|l|}{$\begin{array}{l}\text { State and locel } \\
\text { government employment }\end{array}$} \\
\hline $\begin{array}{l}\text { Medical focilities } \\
\text { (including teaching } \\
\text { hospitel) employment }\end{array}$ & & $\therefore$ & & & & \\
\hline \multicolumn{7}{|l|}{$\begin{array}{l}\text { Industrial omployment } \\
\text { within U.S. }\end{array}$} \\
\hline \multicolumn{7}{|l|}{$\begin{array}{l}\text { Employment with foreign } \\
\text { omployer }\end{array}$} \\
\hline \multicolumn{7}{|l|}{ U.S. militery service } \\
\hline \multicolumn{7}{|l|}{ Other (specify) } \\
\hline \multicolumn{7}{|l|}{ Still soeking employment } \\
\hline
\end{tabular}

